\title{
Algunos aspectos de la arqueología prehistórica de Uruguay
}

Antonio TADDEI ${ }^{1}$

\section{Antecedentes de la arqueología en Uruguay}

El territorio uruguayo constituyó hasta poco tiempo una zona arqueológicamente desconocida. Sólo el esfuerzo particular de aficionados con cierta labor metódica llenó, en pequeña parte, el desinterés oficial por hurgar sus raíces prehistóricas. Esa temática, preferida en la enseñanza media y superior de Uruguay, fue cumplida, con todas las limitaciones emanadas de actuar sin apoyo económico y plena de sacrificios de toda índole, por el Centro de Estudios Arqueológicos de Montevideo, institución privada que nucleó aficionados dispersos pero con clara vocación e interés. La creación posterior por ley del Departamento de Antropología en el seno de nuestra Facultad de Humanidades y Ciencias en el año 1974 cumple con una necesidad largo tiempo anhelada. Desde entonces se trabaja con paso seguro, en un avance conceptual y metodológico que, sin duda, aportará datos más concretos en la reconstrucción del pasado prehistórico de Uruguay.

\section{Breve enfoque fisiográfico del territorio uruguayo}

Es obligado ofrecer de nuestro país un panorama físico del mismo en el sentido de intentar reconstruir, en parte, el medio ambiente en el cual tuvieron desarrollo sus pautas prehistóricas. El territorio de Uruguay, con $187.000 \mathrm{~km}^{2}$ de superficie, se halla comprendido entre los paralelos $30^{\circ}$ y $35^{\circ}$ Lat. S y $53^{\circ}$ y $58^{\circ}$ Long. O. Posee límites políticos con dos grandes naciones sudamericanas: por el norte, con Brasil (Estado de Río Grande del Sur), y por el oeste con Argentina (provincias de Entre Ríos y Corrientes). Posee tierras en general fértiles (con sólo 5\% de "blanqueales" no aprovechables para el agro), cubiertas de excelentes pasturas de las que aprovecha la ganadería local. El clima es templado. La temperatura alcanza en el invierno (julio) a $5^{\circ}$ bajo

1 Director del Centro de Estudios Arqueológicos, Montevideo, URUGUAY. cero; en el verano (enero) las más altas se acercan rara vez a los $43^{\circ}$. La media anual es de $16^{\circ}$. Las lluvias, aunque irregulares, acusan un promedio anual de 950 $\mathrm{mm}^{3}$ en el sur, las que aumentan gradualmente hacia el norte donde precipitan $1300 \mathrm{~mm}^{3}$. Las heladas con un promedio de 25 anuales son más frecuentes en el centro y norte del país. Más de la mitad del territorio uruguayo se halla situado por debajo de los $100 \mathrm{~m}$ respecto del nivel del mar; no posee montañas, y los valores hipsométricos que superan los $200 \mathrm{~m}$ de altitud son un escaso $10 \%$ de su superficie. El territorio de Uruguay se incluye en la penillanura típica, la cual con sus complejas ondulaciones se continúa naturalmente por el vecino estado brasileño de Río Grande del Sur. Esta penillanura presenta tres aspectos principales, que son: el noroeste, que es región plana con suave inclinación hacia el río Uruguay, contiene suelos pedregosos y se conoce por Cuesta Basáltica de Haedo, en la que se incluye el valle del río Uruguay; el noreste, suavemente ondulado y con llanos al que se denomina Penillanura Sedimentaria (contiene capas del Gondwana); y como tercera región, al sur y centro del país, tenemos la Penillanura Cristalina, la cual concentra el $50 \%$ del territorio uruguayo; es ésta, zona de rocas antiguas de diversos orígenes, las que asoman entre sedimentos también ondulados. Estas tres regiones naturales integran una gran variedad de ambientes tales como: planos y anegadizos (con esteros y lagunas), pedregosos, con bosquecillos serranos o adosados a los cursos fluviales, etc., en la que cada uno condiciona un tipo de vegetación. La pradera es, de todas maneras, el tipo de tapiz dominante. La red fluvial de ríos, arroyos y cañadas menores, que se alimentan de lluvias, es densa y de tipo dendrítico. Está compuesta de corrientes de agua dulce relativamente constantes, las que fluyen hacia tres cuencas principales que son: el río de la Plata, el río Uruguay y la laguna Merin. Los árboles son poco frecuentes; pero los márgenes de los ríos y arroyos e incluso las quebradas serranas poseen fuertes montes nativos sobre todo en el norte del país. En particular, el río Uruguay, en el noroeste, ofrece una exuberante y variada floresta de tipo subtropical que llega, intrusiva, desde la 
provincia argentina de Misiones. Desde el punto de vista zoogeográfico, Uruguay se integra en el límite meridional de la subregión Guayánico-Brasileña, la que es considerada como distrito subtropical de aquélla. Esa subregión comprende gran parte de la Mesopotamia Argentina, Chaco Boreal y Central, sur de Paraguay y Misiones. Sobrevive actualmente en territorio uruguayo una gran variedad de mamíferos, aves, peces y reptiles. Otros están en franca retirada. Existían el jaguar, el puma, el ciervo de los pantanos y el lobo grande de río. Subsisten en la actualidad: el mano-pelada (mapache), coatí, erizo (coendú), lobito de río, venado de campo, venado de monte (guazubirá), zorro gris (aguará mirin), carpincho, nutria (coypus m.); armadillos tales como: mulita, tatú y peludo. La avifauna está bien representada y registra 240 especies, entre las que se cuentan el ñandú, patos y gallináceas (perdiz chica y grande, pava de monte, etc.). Hay una nutrida lista de peces de agua dulce de río y arroyos, como ser: tarariras, dorados, surubí, boga, bagres, etc.; en tanto que el río de la Plata, con su régimen estuárico condiciona una parte de esa ictiofauna con otras propias de aguas salinas, tales como corvina, brólala, cazón, merluza, entre otros.

Hemos dado en forma sucinta algunos detalles de la historia geológica del suelo uruguayo y el potencial faunístico que aún hoy pervive. Deseamos con ello ofrecer un panorama geográfico y su deriva ecológica a manera de una desleída imagen de aquella que encontró el aborigen y que le significó un estímulo para el asentamiento humano en el pasado prehistórico. Tal ambiente, en su prístina etapa, constituyó, sin duda, un óptimo económico propicio a la actividad cazadora (y recolectora), cuyas múltiples evidencias arqueológicas lo atestiguan. La marginalidad geográfica del territorio de Uruguay, colocado como un bolsón arrinconado dentro de América del Sur, contribuyó a la perduración y existencia de esas bandas de cazadores, sin problemas de cambios sustantivos en su bagaje cultural.

\section{Objetivos}

Considerado el objetivo de esta comunicación, haremos una caracterización muy general de algunas industrias arqueológicas básicas de Uruguay, de acuerdo a sus contenidos y a la presencia-ausencia de ciertos indicadores culturales. De esas entidades prehistóricas, por razones de espacio, pondremos énfasis en las del tiempo precerámico, sin que por ello dejemos de expresarnos, aunque de manera sumaria, de la presencia de la cerámica por el carácter cronológico de "fósil-guía" que significa esa importante adquisición técnica.

\section{Los cazadores-recolectores primitivos no especializados (inferiores)}

Entre las unidades culturales de la prehistoria uruguaya mencionaremos en primer término una serie de industrias líticas precerámicas de morfología "protolítica", o "lítico inferior", o "prepuntas de proyectil", de bajo grado de tecnología, de las cuales son ya numerosas las evidencias que hemos detectado en nuestro país.

Particularmente ha sido el noroeste, en el departamento de Artigas, la zona que concentra, por el momento, la mayor cantidad de estos testimonios líticos. Los sitios más fértiles de esta tradición los hemos ubicado en la zona del arroyo Catalán Chico, próxima a sus nacientes en la Cuchilla Belén. En el área que comprende $27 \mathrm{~km}^{2}$ hemos localizado 17 yacimientos principales, bien agrupados, en los cuales efectuamos 134 muestreos diferenciados, que rindieron en superficie 19962 piezas líticas. Este tipo de industria es conocida por "catalanense" en la literatura arqueológica americana. La materia prima utilizada con preferencia casi absoluta (99\%) es la arenisca silicificada local (nivel geológico del paleodesierto de Tacuarembó ¿triásicas?). El 1\% restante corresponde a la calcedonia. Ambas son muy comunes en esta zona (Figuras 1 y 2). Aquella tenaz arenisca aparece en forma de rodados (o guijarros) entre los cauces fluviales, o también como filones aflorando sobre las terrazas estructurales del dominante basalto local. La industria es de apariencia tosca y primitiva, pero posee buenos retoques a percusión. En alguna fase, tal vez tardía, se observa un notorio aumento de artefactos más especializados (p.e., perforadores y muescas), con algún esporádico retoque a presión (hay también percusión fina), aunque esa técnica es minoritaria.

De modo general, la industria "catalanense" podemos considerarla como integrada de: $86 \%$ de artefactos elaborados sobre lascas, $13 \%$ de artefactos elaborados sobre núcleos y $1 \%$ de artefactos elaborados sobre guijarros (tipo chopper).

Son escasas y fortuitas las láminas y prácticamente están ausentes las hojas. Un 75\% de los artefactos son raederas, las que en sus categorías de simples, dobles, compuestas y múltiples, se mantienen como 
grupo tipológico dominante. Tan sólo un $12 \%$ son raspadores de filos abruptos en bisel. En esta sección son típicos los nucleiformes piramidales y subpiramidales que a veces transicionan a tronco-cónicos, ambos ejecutados tanto en núcleo como en lasca gruesa. El resto del acervo lítico está constituido por lascas y núcleos simples o con retoques sumarios. Observamos asimismo raspadores en "hocico" o en punta, ambos preformados por escotaduras o muescas, a veces éstas del tipo "alterno". Los perforadores son escasos y la punta activa se observa, en algún caso, asimismo entre muescas "alternas". Son numerosas las lascas con filos, de dorso lateral (que es un talón o un plano de fractura), las que funcionalmente serían cuchillos. Su filo a menudo está retocado con técnica "alternante". Son relativamente frecuentes las raederas, raspadores y muescas de filos activos cóncavos con buen retoque a percusión. Tal presencia, bien manifiesta en esta tradición de cazadores recolectores primitivos "catalanenses", nos ilustra en el sentido de ver en esos litos artefactos especializados que han sobrevivido a la meteorización o, lo que es lo mismo, son testimonios indirectos, imperecederos, del uso de la madera para desbastar con su reentrancia los palos destinados a formatizar lanzas de mano ( $\sin$ soltar), venablos arrojadizos, etc., en los que la punta leñosa, aguzada y endurecida tal vez a fuego y grasa, no sería separable y sí tallada en el mismo palo. Esos artefactos cóncavos serían así, repetimos, prueba indirecta pero objetiva de que sus variadas escotaduras artificiales unen un carácter formal y específico para una determinada función que podría ser el del mencionado desbastado.

Un rasgo técnico que constituye asimismo un fuerte indicador de estas primitivas industrias del "catalanense", son los tipos de retoques que por el momento parecen ser exclusivos o privativos de estas protoculturas de Uruguay. Nos referimos a los retoques marginales "alternos" (es el efectuado en lados y caras distintas de un mismo lito) y a los retoques también marginales "alternantes" (que es el ejecutado en un mismo lado y en caras distintas, a veces en sectores y otros discontinuos). Esta modalidad técnica de retoques ha registrado promedios que oscilan entre $30 \%$ y $37 \%$ de artefactos observados. Predomina, sin embargo, el retoque marginal simple con $73 \%$ de promedio (es el que está limitado a los bordes del lito) y se manifiesta con preferencia en el anverso (o cara dorsal). Observamos además como otro detalle particular del "catalanense" el retocarse el reverso (o cara ventral), del cual registramos entre
$4 \%$ y $13 \%$ de los utensilios. Es escaso y variable el trabajo bifacial, el cual produjo piezas en general espesas y de variada morfología. Hay entre ellos: elipsoides, cordiformes, lanceolados, circulares e irregulares. Estos bifaces han recibido retoques a percusión en casi todo su perímetro, y resultan ser, por ello, artefactos ya terminados. Tipológicamente serían raederas de filos convexos convergentes. Su frecuencia oscila entre $1 \%$ y $4 \%$ para el trabajo bifacial completo y $6 \%$ para el incompleto. En algunas series líticas con piezas de mayores dimensiones los bifaces faltan completamente. Son asimismo escasos los unifaces completos e incompletos con índices de $7 \%$ y $9 \%$, respectivamente. Los artefactos sobre núcleos (con 13\%) y aun los núcleos simples son del tipo piramidal, poliédrico, facetado o amorfo. No hay prismáticos. Se observan además grandes y pesados tajadores en litos discoides, utilizados tal vez en el corte de la madera entre otras funcionalidades (Figuras 3, 4, 5, 6, 7, 8, 9, 10, 11 y 12).

Las dimensiones de esta primitiva industria "catalanense" son variables aun entre sitios contiguos. Algunos exhiben macroartefactos sin bifaces, en tanto que en otros, acaso epigonales y tardíos, hay predominio de piezas pequeñas, las que carecen de pátina y aumentan en bifacialidad. Una aproximación al tamaño de los litos del "catalanense" estaría entre los siguientes porcentajes: $16 \%$ oscilan entre 140 y $100 \mathrm{~mm}, 30 \%$ oscilan entre 99 y $70 \mathrm{~mm}$ y $54 \%$ oscilan entre 69 y $35 \mathrm{~mm}$.

Por supuesto que hay piezas mayores y aun menores dentro de esa escala; pero son escasas.

Ya dijimos que existen diferencias en el contenido desde un yacimiento a otro vecino tanto en su aspecto formal, dimensional y porcentual de sus variados rasgos. No olvidamos que estamos analizando materiales de superficie. No estamos seguros si esas diferencias son atribuibles al hecho de que estamos observando fases temporales y, por ende, diacrónicas, o que nos hallamos en presencia de facies o, lo que es lo mismo, de actividades diferentes y sincrónicas producidas por un mismo grupo humano. Aun con las ventajas de trabajar con series líticas fértiles, estamos inhibidos de manifestarnos concretamente, ya que esa fertilidad cultural puede ser el producto de recurrencias de ocupación de un mismo sitio que estaba cubierto, al que la erosión posterior destapó alterando con la mezcla producida la fisonomía de una ocupación que era primaria y pura. 
Existe en el "catalanense" cierta constancia y regularidad en lo que se refiere a la perduración de la técnica de los retoques ya expresado (con marginales "alternos" y "alternantes" a percusión), al siempre alto porcentaje (99\%) del uso de la arenisca silicificada como materia prima, a su aspecto de tosca y primitiva industria y a la ausencia, en la mayoría de los sitios visualizados, de verdaderas puntas de proyectil líticas, ya sean enteras o fragmentadas. En efecto, sólo en el departamento de Artigas hemos ubicado hasta el momento 24 sitios arqueológicos de superficie (hay dos excavados y varios sondeos), de los cuales en sólo ocho de ellos, entre las 10582 piezas colectadas en muestreos (son artefactos en su casi totalidad), hemos hallado la exigua cuota de 13 puntas de proyectil líticas (cuatro son completas y nueve fragmentadas de los tipos apedunculadas y pedunculadas con aletas). En 15 sitios (de aquellos 24 mencionados) no hemos observado indicio alguno de puntas de proyectil líticas entre 8796 piezas, asimismo recogidas en superficie. ${ }^{2}$

Sin embargo, uno de esos 24 sitios de la localidad del arroyo Catalán Chico, al que hemos siglado 35-S-Perdices, entre sus 2621 piezas recogidas en un área concreta de $85 \times 45 \mathrm{~m}$ aproximados, creemos que ha sido el producto de un grupo "catalanense" influenciado en buen grado por los cazadores superiores, puesto que entre los muestreos allí efectuados hemos recogido: siete puntas de proyectil líticas pedunculadas con aletas (seis completas y una fragmentada) y 34 puntas de proyectil líticas apedunculadas (10 completas, lanceoladas y foliáceas de base convexa y 24 fragmentadas de las que 11 son distales y 13 bases convexas).

Entre estas puntas de proyectil, en una completa y en cinco fragmentos, sus bordes han sido "retomados". Pensamos que en este caso particular del sitio 35-S Perdices, en una etapa transicional de sus ergologías, los "catalanenses" han tenido reales contactos, elaborando entonces puntas de proyectil líticas. $\mathrm{La}$ mayoría de ellas son de tosca factura y asimétricas,

2 No computamos en dichas cifras de material recogido, tres lotes muestreados con un total (aproximado \} de 9800 piezas, colectados en nuestras campañas de 1959, patrocinadas por el Museo Histórico Nacional, la de la Facultad de Humanidades y Ciencias de 1960 y la del Consejo Departamental de Montevideo de 1962. En la segunda y tercera giras participaron, respectivamente, H. Müller-Beck y D. E. Ibarra Grasso. Entre aquella cantidad de piezas, sólo se halló una punta apedunculada que se integró al sitio 35-S-Perdices. y parecen ser el producto de una talla inhábil, pero ejecutadas ya sobre bifaces delgados.

El "catalanense" ha tenido extensiones en el territorio uruguayo con variantes algo desdibujadas respecto de las de estos sitios del arroyo Catalán Chico. Se observan por el momento este tipo de industrias en el arroyo Catalán Grande, en el arroyo Pintado (Los Cerros), en el arroyo Tres Cruces Chico, en la zanja Carapé y Paso Yuquerí sobre el río Cuareim, todos del departamento de Artigas. Hacia el este las vemos en el valle Edén, Cuchilla Negra y Paso Ataques del departamento de Rivera; en el Túnel, del departamento de Tacuarembó y en sierras de Aceguá del departamento de Cerro Largo. Otras evidencias hacia el suroeste y sur de Catalán Chico se denotan en el arroyo Gallero y río Daymán Medio, del departamento de Salto, con estribaciones, al parecer, en Los Pericos del departamento de Soriano, y Sierra de Mal Abrigo en el departamento de San José. Pensamos que en el centro del país, en el que faltan investigaciones, habría alguna estación de la línea "catalanense" en el parador Salus del departamento de Lavalleja, y en el Cerro de los Burros y Sierra Ballena del departamento de Maldonado, ambos como los jalones más meridionales insertos sobre el río de la Plata. ${ }^{3}$ En todos estos casos su dispersión geográfica está signada por el común denominador de su fisonomía técnica y por la ausencia, entre otros elementos, de las puntas de proyectil líticas. Ha habido en todos los sitios mencionados una constante de las reglas de cantidad, calidad y continuidad.

En resumen, el "catalanense" es una industria en general de lascas, del tiempo precerámico, en la que están ausentes, con las raras excepciones apuntadas, las puntas de proyectil líticas, como asimismo faltan las piedras de boleadoras y de honda, los molinos, sus manos y la cerámica. Puede suponerse, incluso, que en los ocho sitios premencionados en los que se recogieron esa ínfima cuota de cuatro puntas de proyectil líticas completas y nueve fragmentadas, esos hallazgos de superficie pueden acaso corresponder al paso de verdaderos cazadores superiores que recorrieron el área y no al "catalanense" local. Estas toscas industrias serán el producto del trabajo de bandas de cazadores recolectores compuestas de varias familias ( 30 a 40 personas?), que habrían

3 Son ya 56 los sitios con industria "catalanense" detectados en territorio uruguayo, a agosto de 1986, siendo siempre el noroeste del país la zona donde se agrupan la mayoría de los yacimientos. 
utilizado en la caza agresivas lanzas de mano sin soltar (?) o venablos arrojadizos de madera tallada sin punta separable. Los datos de la etnografía prueban que tal aserto es factible. Sus asentamientos se efectuaron sobre las orillas de los cauces de arroyos, a veces cursos menores, pero siempre con caza y recolección en los alrededores del campamento, con la piedra adecuada para tallar además de la leña y el agua al alcance de la mano. La mayoría de esos asentamientos son, a nuestro criterio, a la vez talleres y campamentos. Hay entre esas industrias suficientes elementos (raederas, raspadores, lascas-cuchillos, perforadores, etc.) entre esquirlas y desechos de talla que prueban lo expresado.

El doctor Marcelo Bórmida, y nosotros, hemos encontrado en capa al "catalanense" en el departamento de Artigas en condiciones estratigráficas, en el arroyo Catalán Chico, en un subafluente del arroyo Catalán Grande y en el arroyo Tres Cruces Chico, aunque en débiles terracitas. Con inferencia geológica, Bórmida (1964) postuló para la iniciación de este complejo una fecha estimativa situada entre los 8000 y 9000 años AC, con fases posteriores no bien delineadas que serán diacrónicas. Esta industria puede insertarse entre las de tipo "protolítico" en la terminología utilizada por la "Escuela de Buenos Aires" (Menghin 1952), o ya en el "pre-projectil point" (Krieger 1967), o bien en su equivalencia de "lítico inferior" (Willey 1966). Su inclusión en esos estadios está dado por poseer baja tecnología lítica y carencia de puntas de proyectil líticas. Nuestro "catalanense" sería, entre otras, una rama americana de su Precerámico Temprano.

\section{Una industria de guijarros}

Cabe mencionar, además, una singular industria precerámica visualizada por el momento sólo en el departamento de Artigas sobre el río Cuareim y dentro de los cursos bajos de sus principales afluentes. Se le conoce por "cuareimense" (Bórmida 1964). De ella se ha recogido cerca de un millar de piezas líticas muestreadas a lo largo de unos $50 \mathrm{~km}$ en línea recta a lo largo del curso medio del río Cuareim.

La industria se presenta in situ desde un nivel medio de $80 \mathrm{~cm}$ por debajo del piso subaéreo; pero la mayoría de ella se halló en posición secundaria, reptadas de aquel nivel de ocupación en las barrancas que caen al río. El "cuareimense" posee fisonomía aún más tosca que el "catalanense", en razón del alto porcentaje de guijarros tallados que la componen (ver Figuras 1 y 2). Se integra en general de: 39\% de artefactos elaborados sobre guijarros (tipo chopper);
$35 \%$ de núcleos (sobre guijarros), con sólo una o dos extracciones y rastro de utilización de sus filos; $26 \%$ de lascas simples, escasas veces retocadas a percusión y con evidencias de uso directo de los filos procedentes de la talla.

El "cuareimense" no contiene láminas ni hojas. El índice bifacial es prácticamente nulo. Hay unifaces en forma de raspadores de planta circular y los nucleiformes piramidales que se observan en el "catalanense" con el cual ha compartido esa misma zona el noroeste uruguayo. En el "cuareimense" se utilizaron como materia prima guijarros del río Cuareim, de la muy común arenisca silicificada en $92 \%$. El $8 \%$ restante corresponde al basalto, también local, de mala fractura concoidal y sin resistencia (Figura 13).

Bórmida, principal caracterizador de esta primitiva industria, supone que estos grupos habrían practicado una agricultura incipiente por el hecho de haber efectuado sus asentamientos en las propias barrancas del río Cuareim, las que previo limpiado de arbolado y malezas se tornaron más favorables para el cultivo que las terrazas de basalto contiguas, en general pedregosas y carentes de suelos aptos para el agro.

A base de inferencias también geológicas, Bórmida (1964) propuso para el "cuareimense" una fecha con un lapso entre 5000 y 6000 años AC, desapareciendo luego del área. ${ }^{4}$ Piensa, incluso, que pudo corresponder a una rama del "altoparanaense" de la provincia de Misiones. Digamos de paso, que las clásicas clavas bumerangoides de esta industria no han sido halladas en la zona indagada. No han aparecido, asimismo, en este "cuareimense": puntas de proyectil líticas, molinos o sus manos, piedras de boleadoras y de honda, como tampoco cerámica. La gente de este grupo habría sido, a nuestro parecer, principalmente recolectoras, complementando su dieta alimentaria con caza y pesca.

\section{Los cazadores superiores no especializados}

No estamos mejor informados en lo que respecta a este estadio cultural, del que por desgracia, faltan fechados absolutos.

\footnotetext{
4 El arqueólogo Klaus Hilbert, de la misión alemana para el Rescate de Salto Grande, ha conseguido dos fechados absolutos de 1560 y 4500 años AP para esta industria "cuareimense".
} 
Es ésta una tradición bien representada en Uruguay, la cual se presenta con múltiples variantes en sus contextos. Están en proceso algunos radiocarbonos derivados de los trabajos arqueológicos de la misión extranjera que actuó en la zona de Salto Grande. Creemos que el "catalanense" le precede, acaso en un par de milenios, en el pobla-miento uruguayo.

La caza y pesca todo el año y la recolección zafral de ciertos vegetales, huevos y miel habrían sido la actividad económica más importante y seguramente única. Salvo la etnia guaraní, los aborígenes de Uruguay no habrían conocido la agricultura ni la domesticación de animales.

Si trazáramos una hipotética línea este-oeste desde la confluencia del río Cebollatí en la laguna Merin hasta la del río Negro en el río Uruguay, habremos dividido al territorio uruguayo en casi dos mitades iguales: una septentrional y otra meridional, cuyo límite sur es el río de la Plata. Las mayores evidencias arqueológicas de los asentamientos de esas bandas de cazadores superiores con puntas de proyectil líticas (pedunculadas con aletas y apedunculadas) parecen situarse en aquella mitad septentrional del país. Allí los contextos -o mejor, complejos- de superficie son más nutridos de rasgos, caracterizan esta tradición y serán el objetivo de este comentario.

Sus desplazamientos parecen situarse allí, desde la boca del río Cuareim fronterizo con Brasil, los cuales se continúan hacia el sur a lo largo de $280 \mathrm{~km}$ aproximadamente del margen izquierdo del río Uruguay con sitios arqueológicos observados en Bella Unión y San Gregorio (departamento de Artigas), en Boycuá, Espinillar y río Arapey (departamento de Salto), en el arroyo Guaviyú y el arroyo Negro, límite este último entre los departamentos de Paysandú y río Negro. Desde este punto de parada, dichos cazadores superiores se han internado al este y al sureste dentro de dicho departamento de río Negro, alcanzando el río Negro casi al final de su curso medio en la localidad de Palmar de Mujica. Sus manifestaciones industriales son desde ya muy numerosas y evidentes a lo largo del referido río Negro (éste de fuerte caudal en sus $650 \mathrm{~km}$ de recorrido), remontándolo al este-noroeste en casi todo su valle hasta sus fuentes situadas en Río Grande del Sur (Brasil). También los ríos y arroyos tributarios del río Negro han sido escenarios del desplazamiento de esas bandas cazadoras en busca del obligado sustento. Principalmente el caudaloso río Tacuarembó Grande (con sus 200 $\mathrm{km}$ de recorrido en sentido norte-sur), afluente de derecha que le vierte al río Negro al comienzo de su curso medio, es el que acopia en su valle una buena serie de fértiles yacimientos arqueológicos con material bien representativo (ver Figuras 1 y 2). El pasaje de esos grupos cazadores hacia Brasil actual, sea por este río Tacuarembó o ya por el Alto río Negro, está ampliamente confirmado por las correctas investigaciones brasileñas realizadas en ese vecino estado de Río Grande del Sur.

En razón de su riqueza cultural consideramos aleccionador, entonces, pormenorizar el contenido material de sólo los sitios enclavados a lo largo de los ríos Negro y Tacuarembó Grande. Poseen identidad tipológica y técnica que le confieren fisonomía familiar y homogénea. En efecto, esa franja territorial de, aproximados, $300 \mathrm{~km}$ de largo por unos $15 \mathrm{~km}$ promedio de ancho, a la que designaremos desde ahora Area Central, se la situaría así: con un comienzo en el oeste desde el ya expresado Palmar de Mujica próximo al Bajo río Negro, con su extensión este-noreste en tierras hoy anegadas por las represas Baygorria y Rincón del Bonete, con su continuación al norte entrando ya por el valle del río Tacuarembó Grande hasta alcanzar, finalmente, los Bañados de Zapucay. En esa Area Central así delimitada, hemos ubicado personalmente 40 sitios arqueológicos de superficie que rindieron un total de 10700 piezas líticas y la ínfima cuota cerámica de 523 tiestos. Esa área, en razón de sus contenidos, la hemos bipartido en dos principales sectores, que son: un primer sector occidental con 29 sitios (del total de 40 mencionados), que no contiene cerámica (o está escasamente representada), enmarcado entre el referido Palmar de Mujica y que alcanza hacia el este-noreste la ex confluencia del arroyo Carpintería (departamento de Durazno), extensión que calculamos en unos $120 \mathrm{~km}$ en línea recta. La mera presencia de la cerámica en ese primer sector hace que lo consideremos como precerámico. Un segundo sector, situado al este-noreste de aquél, se integra con los 11 sitios restantes, los cuales se presentan ya levemente ceramizados dentro de los $180 \mathrm{~km}$ finales de dicha Area Central. Son sitios insertos en el río Negro Medio y en el curso Bajo y Medio del río Tacuarembó Grande, sector, repetimos, en el cual se recogieron en superficie 523 tiestos cerámicos (428 lisos y 95 decorados).

El tipo de asentamiento de estos cazadores superiores especializados ha sido el establecimiento de sus campamentos sobre alturas próximas a los ríos y arroyos fuera del alcance agresivo de las crecientes, 
con agua, leña, caza, pesca y recolección en sus inmediaciones. Cambiarían de sitio una vez agotadas las posibilidades económicas de sustento del grupo. La casi totalidad de esos 40 sitios del Area Central se asientan sobre terrenos medanosos. No debemos pensar que esos sitios deben ser contemporáneos. Por el contrario, deben existir entre ellos cientos de años de diferencia.

Reiteramos que existe una cierta unidad cultural en los sitios enclavados dentro del Area Central, cuyos componentes industriales más relevantes son los siguientes (Figuras 14, 15, 16, 17, 18, 19, 20 y 21):

- Puntas de proyectil líticas pedunculadas con aletas, bifaciales y variada morfología. Sólo un tipo, que denominamos Yaguarí; su zona de dispersión es el río Tacuarembó Grande. Las dimensiones de estas tan corrientes puntas de proyectil oscilan entre 35-20-6 mm y 50-22-8 $\mathrm{mm}$. Son escasas las de mayor tamaño. Están representadas, en general, con $7 \%$ de los hallazgos (excluidos lascas y núcleos simples). Se elaboraron a presión.

- Puntas de proyectil líticas apedunculadas, las cuales con $2 \%$ de frecuencia aparecen asociadas a las pedunculadas. Son bifaciales, y algunas observan presión. Hay alta popularidad en las de limbo y base convexa. Siguen las de base recta o subrecta. Están prácticamente ausentes las de base escotada o cóncava. Sus formas son lanceoladas, foliáceas y triangulares. Las dimensiones son variables: las pequeñas oscilan entre $50-35-8 \mathrm{~mm}$ y 40-20-6 mm, en tanto que las mayores están entre 60-31-10 mm y 75-32-10 $\mathrm{mm}$. Son escasas las que superan esas medidas.

- Bifaces de variadas morfologías, tales como lanceolados, elipsoides, circulares, cordiformes e irregulares. Poseen, en general, en especímenes enteros, el tamaño y espesor tanto de las puntas de proyectil pedunculadas como de las apedunculadas. Consideramos que estos bifaces son las verdaderas "preformas" de dichas puntas. Estos bifaces completos (o enteros) son delgados, y cuando poseyeron el largo, ancho y espesor adecuados, se los ha retocado a presión en todo o casi todo su perímetro. Con esta forma y acabado serían utilizadas como raederas o bien como cuchillos, pero principalmente como elemento de reserva, casi terminado, para una rápida elaboración, a base de ella, de las puntas de proyectil pedunculadas o apedunculadas. Las fragmentadas en ese proceso (de elaborar puntas) y sin el largo necesario para cumplir esa finalidad fueron aprovechadas, "retomadas", reduciéndolas a las raederas bifaciales que hallamos con tanta frecuencia en las formas circulares, elipsoides, pequeñas en general, las cuales fueron retocadas en todo su contorno. Otros fragmentos se han "retomado" en perforadores e incluso en raspadores, aprovechando los planos de la fractura. Estos bifaces enteros y fragmentados constituyen el $10 \%$ promedio de los hallazgos.

- Los artefactos que denominamos "hoces", en razón de su peculiar forma, son privativos del río Tacuarembó y de la localidad de San Gregorio (Polanco) en el río Negro Medio. Enmangados actuarían como perforador apical (?) y su muesca retocada como raedera cóncava (?). De menores dimensiones y más toscas aparecen, asimismo, en Cabo Polonio (departamento de Rocha). Sus medidas (promedio) son de 40-23-9 mm.

- Un escaso $1 \%$ corresponde a molinos planos, los cuales con sus respectivas manos (éstas se integran con 1.5\%) son frecuentes en el Area Central. Estos implementos de molienda señalan una alimentación mixta, significando que hubo recolección y preparación de elementos vegetales en la dieta. Las dimensiones de los molinos promedian 250-190-50 mm y habrían sido destinados además a la molienda de pigmentos para pintura corporal. Algunas manos han aparecido teñidas de rojo. Son corrientes, asimismo, los hallazgos de molinos con acanaladura profunda de forma elipsoide en los cuales, con agua y arena como abrasivo, recibirían el pulido las piedras de boleadoras y el alisado las de honda (lenticulares).

- Las piedras de boleadoras con y sin ranura se integran en $2.5 \%$ de estas series de artefactos de cazadores superiores. Las de mayor frecuencia son las del tipo Bf, y en orden decreciente el B2 y el $\mathrm{Bc}$. En gran mayoría utilizaron basalto en su confección.

- Las piedras de honda (lenticulares) están representadas en $1 \%$. En general son de basalto. Hay mayoría de las alisadas respecto de las talladas. Son escasas las pulidas. La parte central del actual lago del Rincón del Bonete es la zona de la mayor concentración de este elemento cultural.

- Las "estecas" son artefactos de arenisca friable; serían destinadas a desgastar madera (?), en la preparación de astiles y arcos, entre otros. 
- Las piedras con "hoyuelos" (en general de un único hoyuelo) son comunes en el Area Central. Se produjeron sobre rocas de areniscas friables (blandas). Son del tipo picoteado, y en media esfera de hasta $3 \mathrm{~cm}$ de diámetro. Son escasos los hoyuelos pulidos. Su función nos es desconocida, ¿rompecocos? o ¿para tornar rústica la punta de los palillos de hacer fuegos?

- Las piedras de arenisca, asimismo friables, con canaletas, participan de estas ergologías. Dichos canales artificiales fueron producidos en el afilado de puntas de madera, o bien de punzones de hueso ¿o de tembetás? Puede designársele como "afiladores en canaletas".

- Los trituradores son guijarros cuyos bordes aparecen desgastados, a veces formando carenas, por efecto de la frotación. Accionarían, tal vez, con el carácter de manos en la cavidad rústica de los molinos (¿para trituración de ocres?).

- Los trozos amorfos de sedimentos litificados de tono rojo, que se convierten a veces en pequeños molinos y que fueron destinados a la extracción de aquel polvo rojo. El raspado originó, incluso, canaletas o estrías. En el Area Central ese sedimento corresponde a la Formación San Gregorio. El color rojo sería destinado a pintura corporal.

- A la lista precedente debemos agregar yunques de piedra (son guijarros globulosos) con la corteza picoteada, sobre el cual se efectuó la talla lítica y además numerosos percutores de piedra que son simples guijarros. Sabemos que no son elementos diagnósticos. Se completa el patrimonio material del Area Central con un esmerado utillaje lítico compuesto, en general, de $9 \%$ de raederas varias y $21 \%$ de raspadores, de los cuales el nucleiforme piramidal es el más corriente (¿procede de la herencia "catalanense"?). Ese es el único rasgo en el acervo de estos cazadores superiores para intentar alguna correlación industrial con aquella protocultura. Y hay que convenir que es poco para establecer una comparación. Hallamos además perforadores típicos, muescas simples (sin retoques), lascas simples filosas, las cuales, con baja frecuencia, se han retocado a presión controlada y que servirían como elementos de cortar (¿cuchillos?). Los retoques de esta industria se han efectuado, de forma persistente, percutiendo el lito (lasca, lámina u hoja) desde el plano de lascado que contiene el bulbo y se denotan con muy alta frecuencia, por lo tanto, en el anverso (o dorso) de la pieza.

En lo referente a la materia prima utilizada en el Area Central es, en todos los casos, la propia de cada región. Así es que, en el río Negro Medio, se acudió a la caliza silicificada y al ópalo (éste es una variedad de aquélla). En el río Tacuarembó Grande, en su curso medio y bajo, la caliza silicificada comparte porcentajes parejos con la arenisca silicificada. Con menor frecuencia se observan jaspe, cuarcita, madera opalizada y mineral de hierro. En este último material se da el hallazgo de algún esporádico rompecabeza que debe ser foráneo. No es habitual su presencia en el Area Central.

Ya dijimos que en este segundo sector oriental de la región comentada, la cerámica aparece aislada y escasa. Creemos por ello que habrá tenido allí un tardío desarrollo. Prepondera la cerámica lisa. Los motivos decorativos (18\%) parecen tener un carácter local. No hay por el momento algún asidero para postular relaciones fuera de esa zona. La Fase Ibirapuitá, ubicada en el centro-sur del estado de Río Grande del Sur (Brasil), cercana a este segundo sector, podría tener una conexión genética o histórica con lo nuestro, sobre todo si nos atenemos a los indicadores líticos.

El análisis de los contextos (o complejos) del Area Central resiste una formal comparación con varios yacimientos de aquel estado brasileño. Con un contenido material muy similar al que estamos comentando, se han observado sitios en los ríos Pardo, Pardinho, Caí, en Itaquí y en el cerrito Dalpiaz entre los más importantes. En Dalpiaz (Miller 1969) se fecharon contextos con similitudes a los del Area Central entre 4000 y 6000 años AP. Estas dataciones determinarían que nuestras vinculaciones prehistóricas con Río Grande del Sur sean más tempranas que las comúnmente sugeridas para Pampa y Patagonia argentinas, cuyos fechados para las puntas de proyectil pedunculadas con aletas son tardíos y del comienzo de la era (40 y 240 DC). ${ }^{5}$

Digamos de paso, que en el Area Central la presencia "catalanense" no ha sido aún advertida. Por

5 Los arqueólogos Klaus Hilbert y Wesley Hurt, ambos de la misión de Rescate de Salto Grande, han conseguido dos altas fechas para estos cazadores superiores, en El Tigre y en Calpica de 10420 y 9320 años AP, respectivamente. Estos sitios están en el departamento de Artigas, en el noroeste del país. 
el momento parece haber sido exclusiva de los cazadores superiores.

Fuera del Area Central y la de los desplazamientos ya expresados sobre el río Uruguay (desde el río Cuareim hasta el arroyo Negro), las evidencias de estos cazadores superiores en el territorio uruguayo son observadas en la costa occidental de la laguna Merin con algunos enclaves intermedios que pautan esa trashumancia. Son ejemplos el sitio Las Marías (Baeza 1974) y el "zapicanense" (Fernández 1976). Estos cazadores llegaron desde la laguna Merin hacia el suroeste, cuyos campamentos se observan en Cabo Polonio (departamento de Rocha), recorriendo un trecho de la costa atlántica.

Otro parece ser el panorama arqueológico en la mitad meridional del territorio uruguayo, al sur de aquella arbitraria línea este-oeste ya expresada (confluencia del río Cebollatí en la laguna Merin a la del río Negro en el río Uruguay). Estos cazadores superiores en sus desplazamientos hacia el sur desde el Area Central han ido abandonando progresivamente la confección y uso de las puntas de proyectil líticas, utilizando en sustitución de ellas la madera y/o hueso, conservando, sin embargo, el resto de su patrimonio material consistente en piedras de boleadoras, molinos y manos. Desaparecen entonces, paulatinamente esas puntas de proyectil líticas e incluso las piedras de honda (lenticulares), a la par que ocurre un empobrecimiento notorio de su instrumental lítico. Ese gradual abandono de la confección de puntas líticas que ya no se observan en los sitios adosados al río de la Plata puede atribuirse, tal vez, a una falta de materia prima adecuada para tallarlas. En esta mitad meridional de Uruguay, en la que impera el Basamento Cristalino, éste habría sido la causal del cambio de la piedra por la madera ante la imposibilidad de obtener rocas de fractura concoidal. Una excepción de lo expresado para los yacimientos arqueológicos del río de la Plata (además de los de Cabo Polonio), pero que confirmaría aquella presunción, es la aparición de un interesante sitio inserto en la cima del Cerro de los Burros (departamento de Maldonado), en el cual, con disponibilidad allí de buena materia prima para elaborar su herramental (hay pórfido felsita), han desarrollado un aleccionador taller de puntas líticas apedunculadas netamente precerámico (Menghin 1977).

Cabe mencionar además a los cazadores superiores con el particular tipo de asentamientos sobre "cerritos", cuyo origen antrópico está fuera de duda. Hay centenares de ellos levantados artificialmente en áreas anegadizas del este y noreste de nuestro territorio, aunque de diferentes contenidos culturales. Así es que los de los departamentos de Rocha y Treinta y Tres son ceramizados y con puntas de proyectil elaboradas en hueso. Son éstas, áreas sedimentarias, y falta allí la piedra. Por el contrario, los "cerritos" de Aceguá (departamento de Cerro Largo) y Vichadero (departamento de Rivera) contienen en su acervo puntas de proyectil líticas además de piedras de boleadoras, molinos y manos. Han mantenido un seguro contacto con los grupos de cazadores superiores del Area Central, con los que, en cierta medida, han compartido la región.

Este panorama con "cerritos" se repite asimismo en el margen izquierdo del Bajo río Uruguay (es un ejemplo el cerrito de La Concordia), que son áreas profusamente ceramizadas en las que también por ser sedimentarias y, por ende, sin piedra para tallar, el aborigen debió utilizar la madera y el hueso en sustitución de aquélla para confeccionar las puntas de proyectiles.

Si bien hemos detallado con cierto énfasis el acervo material de los cazadores superiores del Area Central, ello no significa que existe similar panorama en el resto del país. El único común denominador de estos cazadores será, en todos los casos, las puntas de proyectil líticas, principalmente la pedunculada con aletas. Pero en varios casos observados, el material que consideramos asociado a esas puntas es diferente de un sitio a otro dentro de esa tradición. En algún sitio se presenta como único indicador la referida punta de proyectil lítica acompañada de un pobre inventario lítico sin retoque alguno. En otros, anexa piedras de boleadoras y molinos, y ya en fases tardías adquiere, por contacto, la técnica de la cerámica. El panorama en esta tradición es, pues, muy matizado.

Corresponde, finalmente, situar estas industrias de cazadores superiores, de acuerdo a su contenido ergológico, pero fundamentalmente por la posesión de puntas de proyectil y prescindiendo de las que poseen cerámica, en aquellas de carácter "miolítico" en la terminología usual para la "Escuela de Buenos Aires", o bien entre las de tipo "paleoindio" (Krieger 1964), e incluso en su equivalente de "lítico superior" (Willey y Phillips 1967).

Los contextos (o complejos) con cerámica, por su parte, pueden encuadrárseles en el "paraneolítico" 
(sensu Menghin) o, lo que sería lo mismo, en el "ceramolítico" (sensu Austral).

\section{Fechados radiocarbónicos para Salto Grande}

En ausencia de cronologías en Uruguay, derivadas de la falta de fechados absolutos hasta el año 1976, justo es consignar que el Centro de Estudios Arqueológicos de Montevideo, en sus campañas realizadas en Salto Grande desde 1972, adelantándose al salvamento arqueológico encomendado a Unesco, pudo obtener tres dataciones (son las tres primeras para nuestro país) mediante el procedimiento del radiocarbono. ${ }^{6}$

Así es que en la Isla de Arriba (o Salto Grande) se fechó un nivel $(40-50 \mathrm{~cm})$ con cerámica y lítico en $2370 \pm 80$ AP. Se verificó además en este Corte 3, con estratigrafía adecuada y por debajo de ese nivel cronologizado, un piso precerámico igualmente de lascas. Tras un hiato estéril se halló una tercera ocupación por los $1.15 \mathrm{~m}$, con puntas de proyectil líticas pedunculadas con aletas, acompañadas de artefactos silíceos pequeños (bifaces y lascas). Este último nivel corresponde entonces a cazadores superiores especializados y puede asignársele una fecha tentativa entre 4000 y 5000 años AP.

En la misma Isla de Arriba un Corte 9 rindió por los 30-40 cm otro fogón, cuyo carbón cultural asociado también a cerámico y lítico (con analogías al contenido del Corte 3) produjo una fecha radiocarbónica de $1140 \pm 100$ AP $(810$ DC). En este Corte 9 se hallaron "estecas" de arenisca friable que faltan en el nivel cerámico del Corte 3 . Tras otro nivel estéril, aparece en este Corte 9 un piso precerámico con las mismas características del segundo nivel del Corte 3 , que sería, tal vez, su prolongación, ya que éste se halla tan sólo a $11 \mathrm{~m}$ al noroeste de aquél.

Otra cuadrícula realizada en la Isla del Medio, unos $330 \mathrm{~m}$ al sur de los mencionados, se excavó el Corte 1. A 50-60 cm de profundidad se ubicó un piso ocupacional con cerámica y lítico e incluso carbón también cultural. Su proceso nos deparó un tercer fechado de 2350 \pm 80 AP, coherente con el Corte 3 de Isla de Arriba.

6 Cúmplenos consignar la valiosa mediación de los Dres. Meggers y Evans, del Departamento de Antropología del Smithsonian Institute (Washington D. C.), para realizar el proceso de los referidos radiocarbonos, los cuales se efectuaron en Rikagaku Kenkyusho (Japón).

\section{Conclusiones}

Hemos desarrollado un bosquejo muy general de las principales tradiciones prehistóricas de Uruguay.

Una primera expresión fue referida a los cazadores recolectores primitivos no especializados (o inferiores), con industria lítica con predominio de lascas (86\%) y menor frecuencia de núcleos (13\%), del tiempo precerámico, conocida por "catalanense". Hemos tomado como sitios-tipo los del noroeste de Uruguay de la localidad del arroyo Catalán Chico (departamento de Artigas). Excepto en un sitio aculturado, estas industrias carecen, entre otros elementos, de puntas de proyectil líticas. Presumimos que como tales habrían utilizado la madera y/o hueso. Se trata entonces de un "protolítico" o sus términos con cierta equivalencia de "pre-projectil point" o de "lítico inferior". Con inferencias geocronológica se asigna a esta tradición fecha de inicio entre 8000 y 9000 años AC.

En segundo lugar se dan detalles de otra industria precerámica, prevalentemente de guijarros y menos lascas sin retoques, conocida por "cuareimense", la cual se observa sobre el río Cuareim (departamento de Artigas). Con apoyo, asimismo, geológico se le concede fecha estimativa entre 5000 y 6000 años AC. Bórmida, su principal caracterizador, piensa que los beneficiarios de esta tosca industria habrían sido protoagricultores.

Una tercera exposición se centra en los cazadores superiores generalizados. De esta matizada tradición ofrecemos un particular enfoque del contenido (en cultura material) del Area Central, en razón de su variedad ergológica. No existen por el momento fechados absolutos de esta tradición para nuestro país, y se aguardan los de Salto Grande obtenidos por la misión que actuó por Unesco. En su defecto tenemos en cuenta los fechados de Miller en Dalpiaz (Río Grande del Sur, Brasil), los cuales aseguran la existencia de estos cazadores superiores allí entre 4000 y 6000 años AP. Esta tradición, cuando posee carácter precerámico, puede clasificarse entre las de tipo "miolítico" o "paleoindio", o "lítico superior".

Complementaria de esos cazadores superiores, clasificamos como tales a los que en Uruguay erigieron los "cerritos" artificiales sobre zonas sedimentarias y anegadizas. Están en proceso algunos fechados de contextos de los grupos que tuvieron este particular modelo de asentamiento.

Finalmente, comunicamos los tres primeros fechados radiocarbónicos efectuados en Salto Grande por el 
CEA. Ellos nos ilustran en el sentido de establecer la existencia de grupos que elaboraban cerámica ya por la temprana fecha de 2370 años AP. Tales procesos fueron efectuados con el apoyo siempre invalorable hacia nuestra labor por los doctores Meggers y Evans, del Departamento de Antropología del Smithsonian Institute.
Tenemos plena conciencia de la precariedad del panorama arqueológico presentado para Uruguay. Con un nuevo y adecuado enfrentamiento puesto en marcha en este último trienio surgirán, sin duda, nuevos datos que nos expresarán mejor acerca de esas estructuras prehistóricas y de su real complejidad.

\section{REFERENCIAS CITADAS}

BORMIDA, M., 1964. Las industrias líticas precerámicas de] Arroyo Catalán Chico y el Río Cuareim (depto. de Rivera, Uruguay). Rivista di Scienze Preistoriche XIX: 1-4.

— 1964a. El Cuareimense. Publicación del Seminario de Estudios Americanos. Homenaje a Márquez Miranda, pp. 105-128. Madrid.

CAMPA, R. y D. VIDART, 1962. La cultura precerámica del Catalán. Amerindia 1: 1-28.

MENGHIN, O., 1977. Nuevas investigaciones en los yacimientos del Cerro de los Burros, Montevideo.

MILLER, T., 1969. Resultados preliminares en el sitio precerámico R.S.-LN-1, Cerrito Dalpiaz. Iheringia, S. Antropología 1,43 ss.
GRADIN, C. y M. A. TAMERS, 1975. Tres fechados radiocarbónicos para la Cueva de las Manos. Estancia Alto Río Pinturas (prov. de Santa Cruz). Relaciones IX.

TADDEI, A., 1964. Un yacimiento precerámico en Uruguay, Rev. Baessler-Archiv. Band XII, Berlín.

- 1968. Yacimientos precerámicos en Uruguay. Actas y Memorias del $37^{\circ}$ Congreso Internacional de Americanistas, pp. 315-324, Mar del Plata.

1969. Un yacimiento de cazadores superiores del Medio Río Negro-Uruguay. Anales del $3^{\text {er }}$ Simposio de Arqueología del Area del Plata y adyacencias. San Leopoldo, Río Grande del Sur.

VIDART, D., 1968. Las tierras sin fin. Enciclopedia uruguaya vol. 1, Montevideo. 


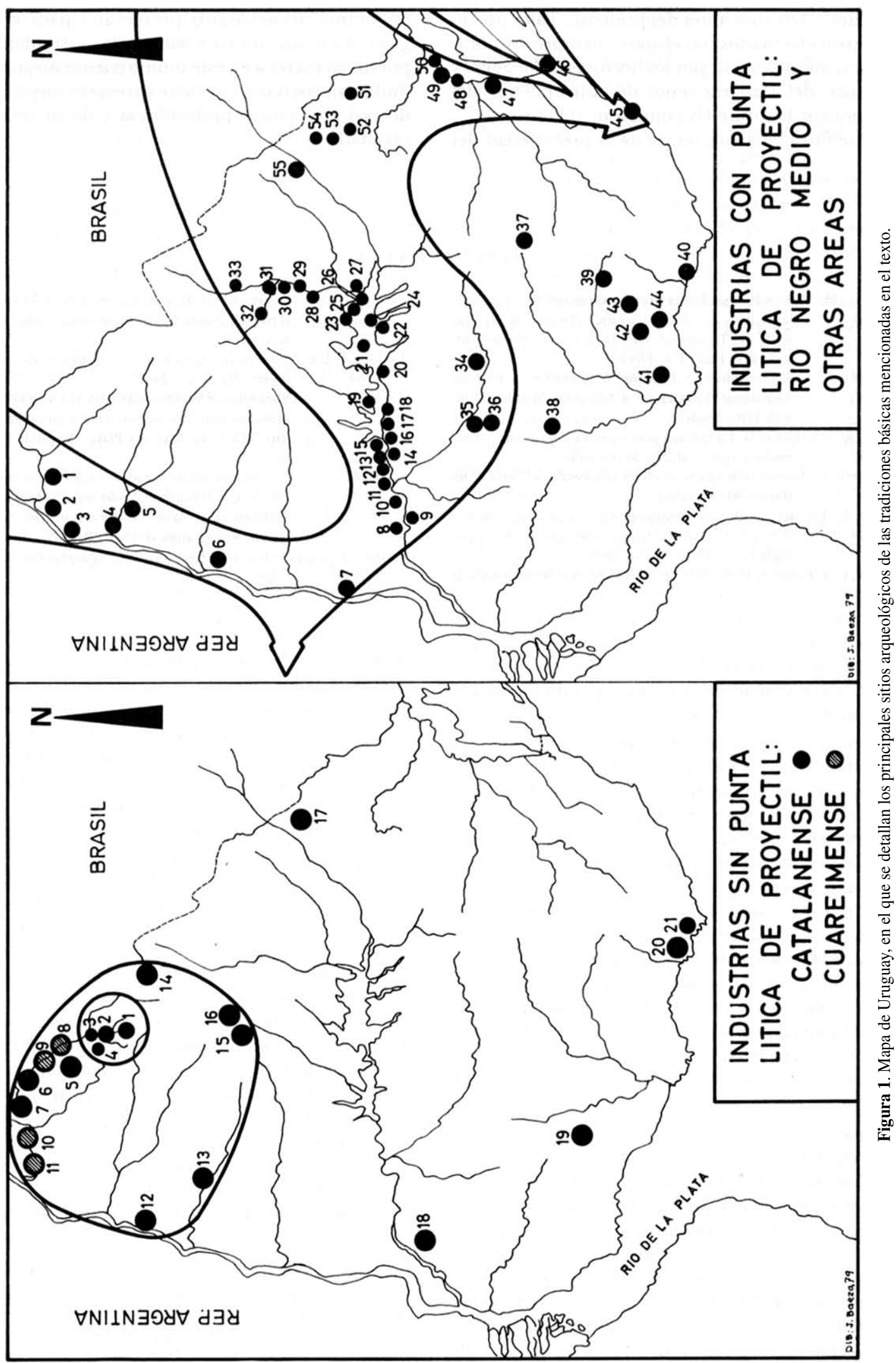




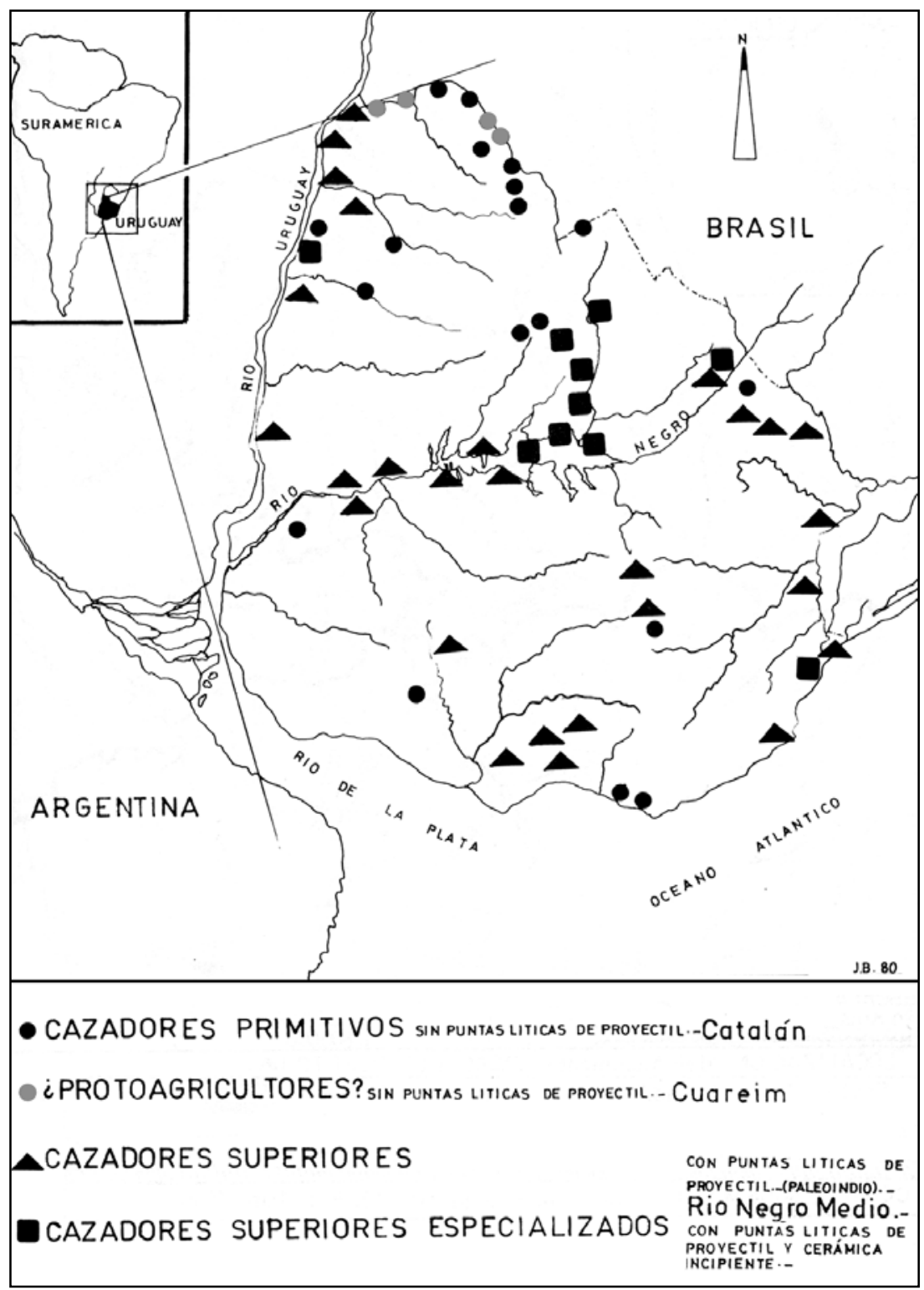

Figura 2. Mapa que indica la distribución de las tradiciones mencionadas en el texto. 

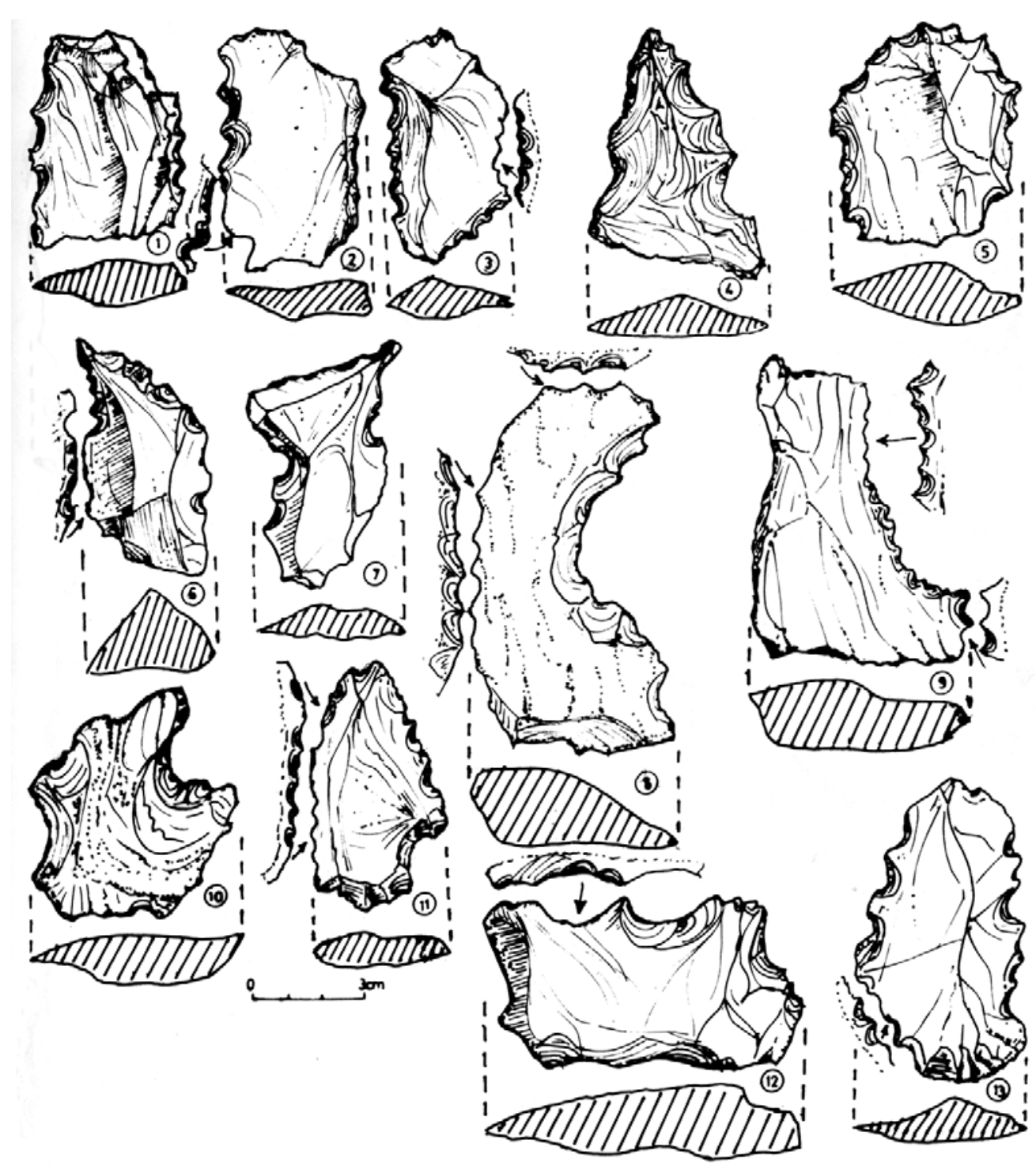

Figura 3. Catalanense: 1) Raedera recta denticulada y raspador convexo opuesto; 2) Raedera recta denticulada;

3) Raedera cóncava-convexa alternante; 4) Doble muesca retocadas opuestas; 5) Raedera (doble): recta-convexa convergentes;

6) Perforador apical; 7) Perforador lateralizado y raspador cóncavo; 8) Raedera cóncava lateral y raspador apical alterno;

9) Raedera cóncava con retoques alternantes; 10) Muesca retocada; 11) Raedera (doble): recta-convexa y muesca retocada;

12) Raspador punta entre muescas alternantes; 13) Raedera triple recta dentada. 


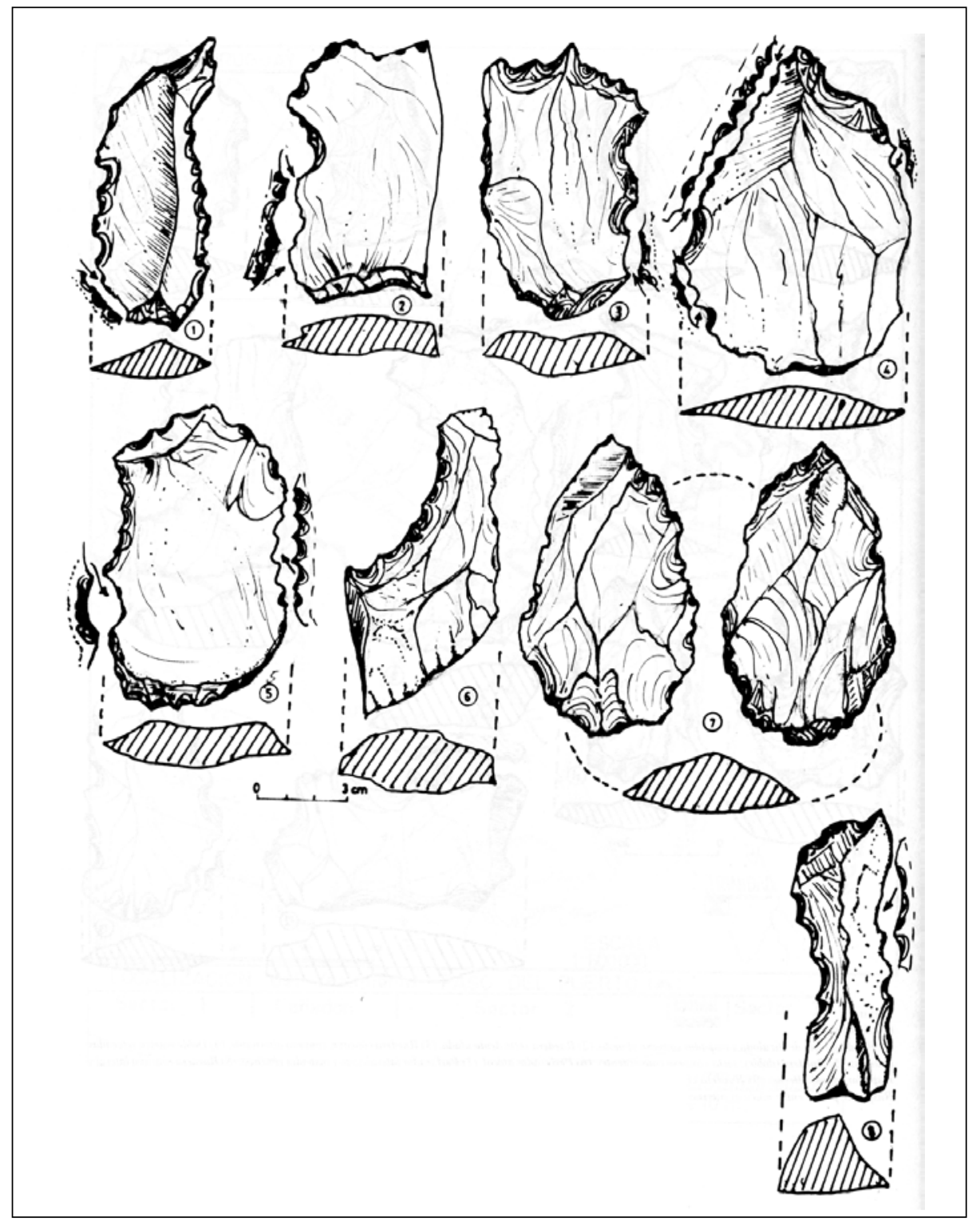

Figura 4. Catalanense: 1) Perforador apical y raedera (doble): cóncava-convexa; 2) Raedera punta roma entre muescas alternantes y muesca en ápice; 3) Perforadora raedera (doble): cóncava-recta; 4) Raedera (doble): recta-convexa convergentes;

5) Raedera punta entre muescas alternantes y raspador cóncavo opuesto; 6) Raspador lateral cóncavo;

7) Bifaz espeso. Sería raedera de filos convexos convergentes; 8) Raedera de filos cóncavos en diedros con retoques alternantes. 


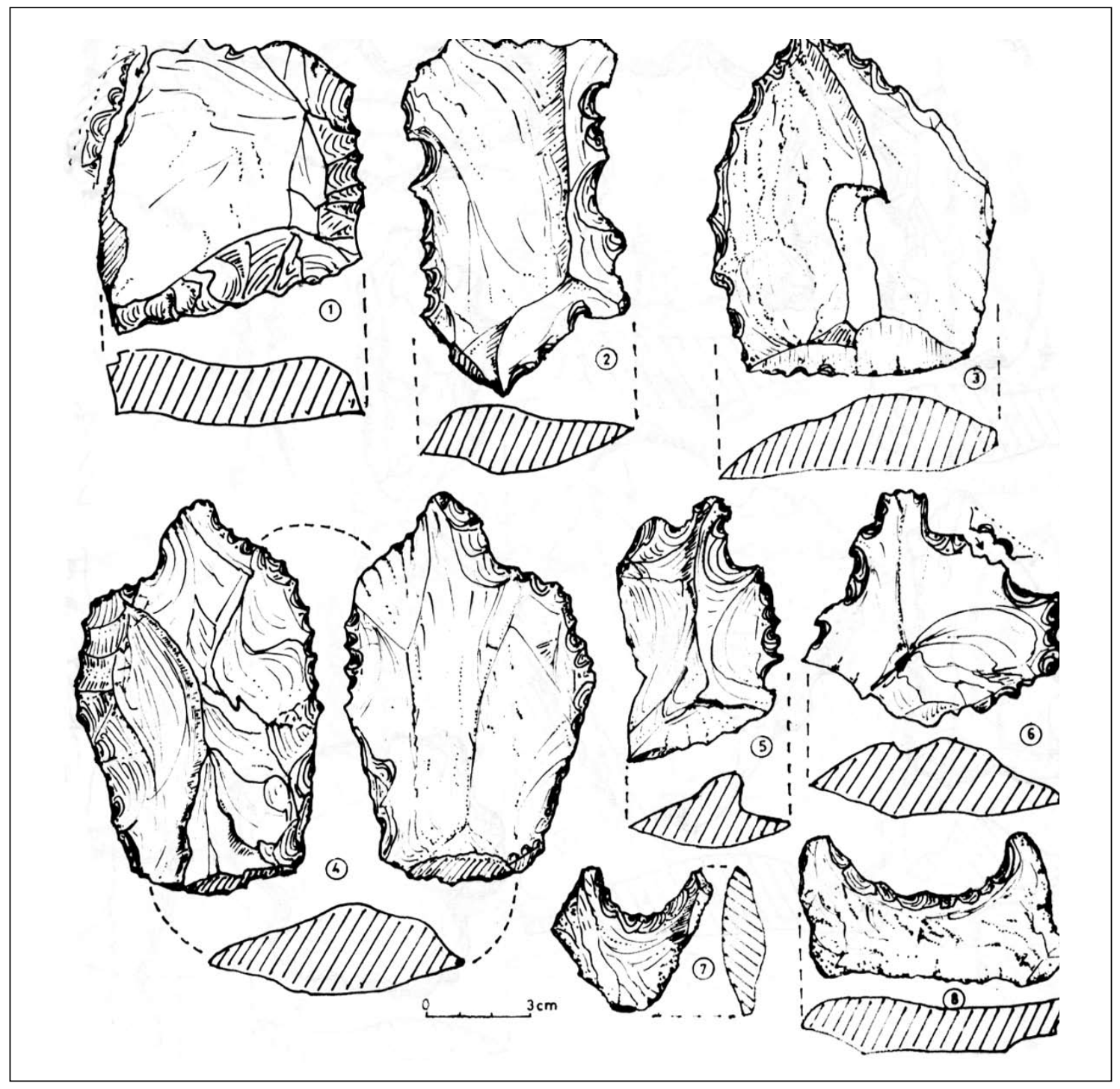

Figura 5. Catalanense: 1) Raspador (doble): recto-convexo convergentes más ídem convexo alterno; 2) Raedera recta lateral, ídem recta en ápice y raspador recto lateral; 3) Raedera (doble): recto-convexa convergentes; 4) Bifaz incompleto (es raedera punta roma entre muescas y doble convexa en laterales); 5) Raspador "en hocico" entre cóncavos retocados y raedera convexa; 6) Raedera doble recta denticulada convergentes; 7) Muesca retocada; 8) Raspador cóncavo en lateral. 


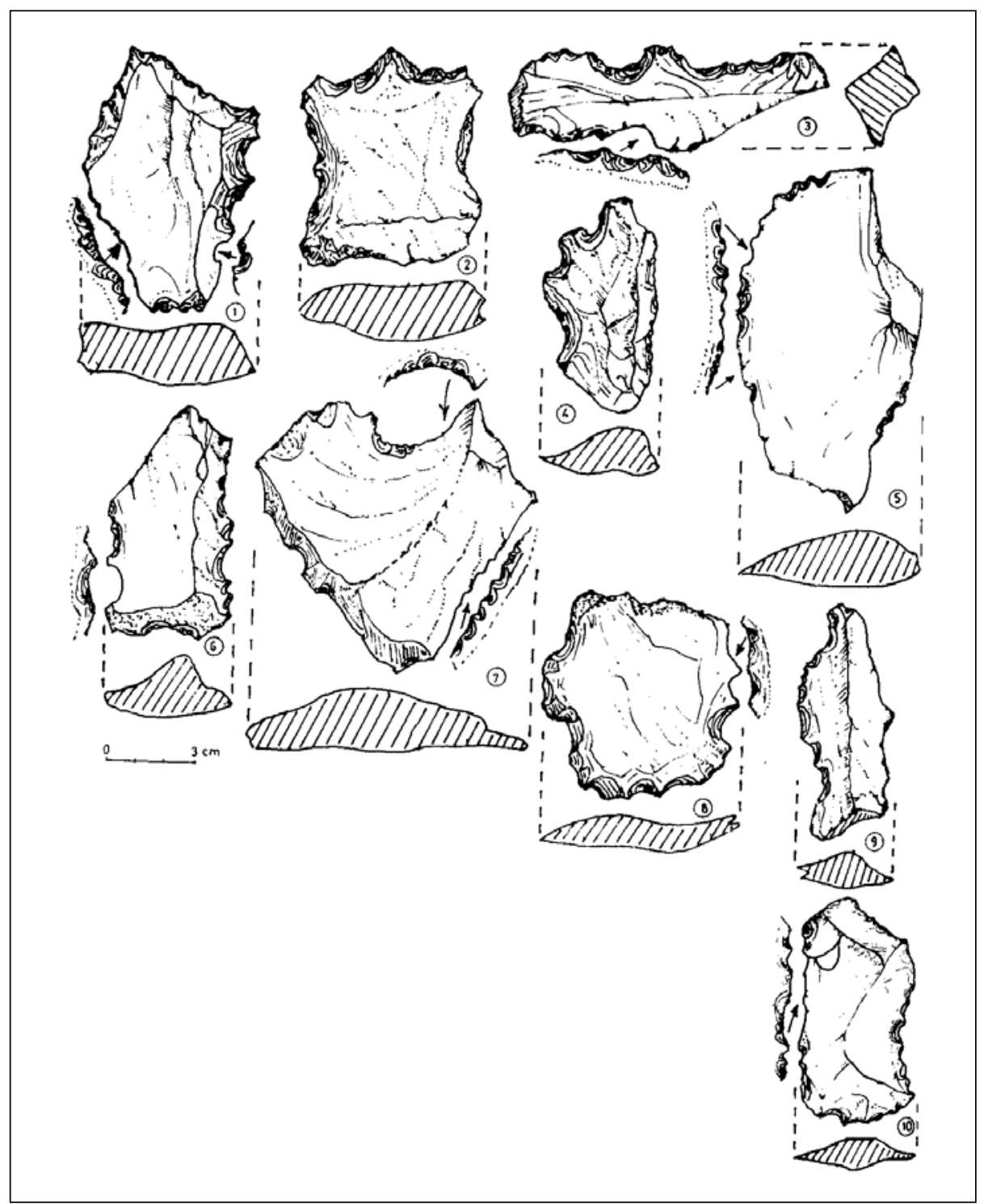

Figura 6. Catalanense: 1) Raspador triple recto y cóncavo alterno; 2) Raspador (doble): en punta entre cóncavos y cóncavo convergentes;

3) Raedera punta roma entre muescas y cóncavo lateral, ídem cóncava alterna; 4) Raedera triple hocicos y cóncava convergentes;

5) Lasca con retoques alternantes (funcionalmente sería cuchillo de dorso); 6) Raspador recto en lateral y muesca alterna opuesta;

7) Raedera (doble): cóncava-recta alternas; 8) Raspador "hocico", raedera convexa y muesca; 9) Lámina con muesca y raedera lateral cóncava-convexa; 10) Hoja en raedera (doble): cóncava-recta en laterales opuestos. 


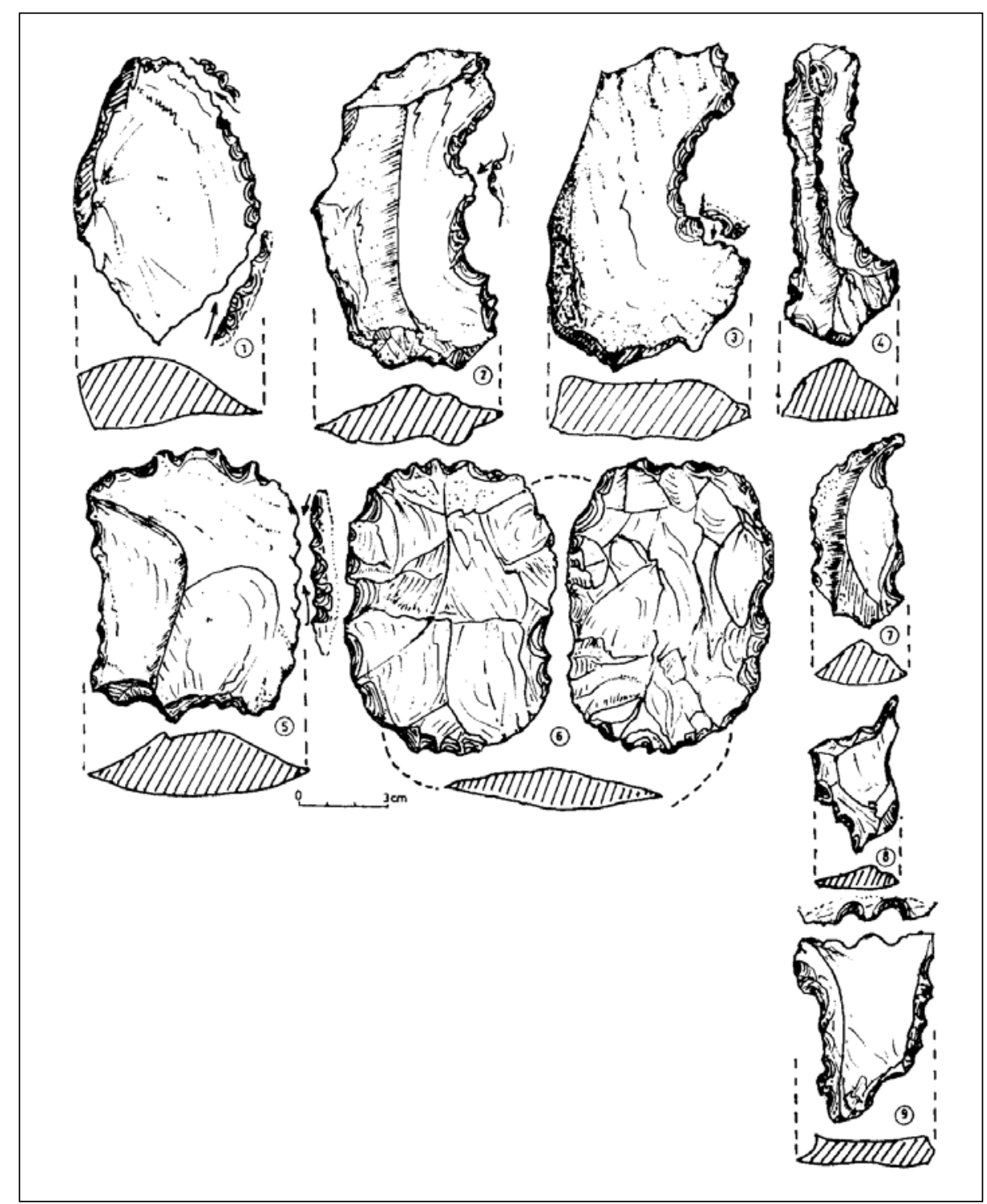

Figura 7. Catalanense: 1) Lasca con filo convexo retocado alternante, sería cuchillo de dorso; 2 y 3) Raederas cóncavas con "hocico" central; 4) Lámina con diedros retocados recto-cóncavos; 5) Raedera doble convexa y raedera subrecta convergentes; 6) Bifaz elipsoide (sería raedera de filos convexos convergentes); 7) Perforador apical lateralizado. Lados retocados en raederas convexas; 8) Perforador lateralizado; 9) Raspador (doble): cóncavo-convexo e ídem en punta entre muescas alterno. 


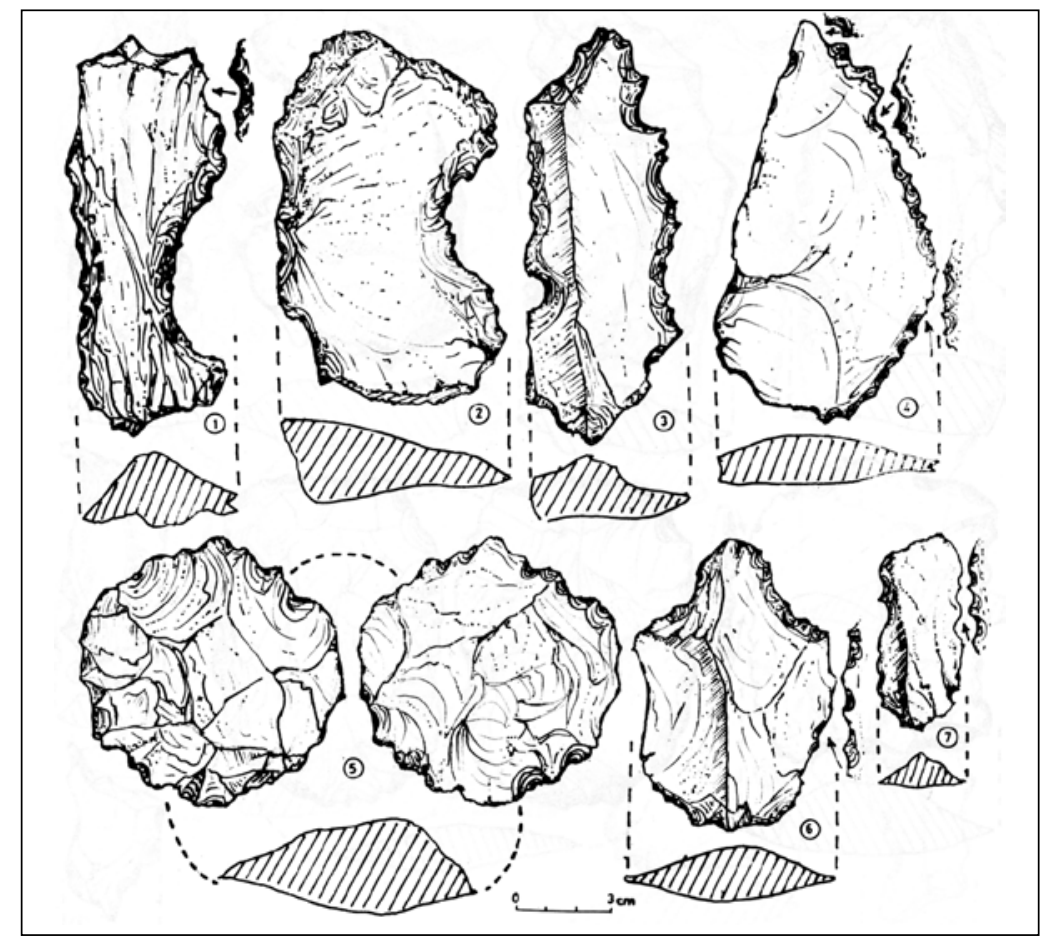

Figura 8. Catalanense: 1) Raspador cóncavo y muesca alternante en lateral; 2) Raedera cóncava; 3) Raedera leve convexa denticulada en lateral; 4) Raedera convexa simple (o ¿cuchillo?); 5) Bifaz circular espeso (raspador de biseles convexos);

6) Raedera (doble): cóncava-convexa alternantes; 7) Lámina con retoques convexos y punta entre muescas.

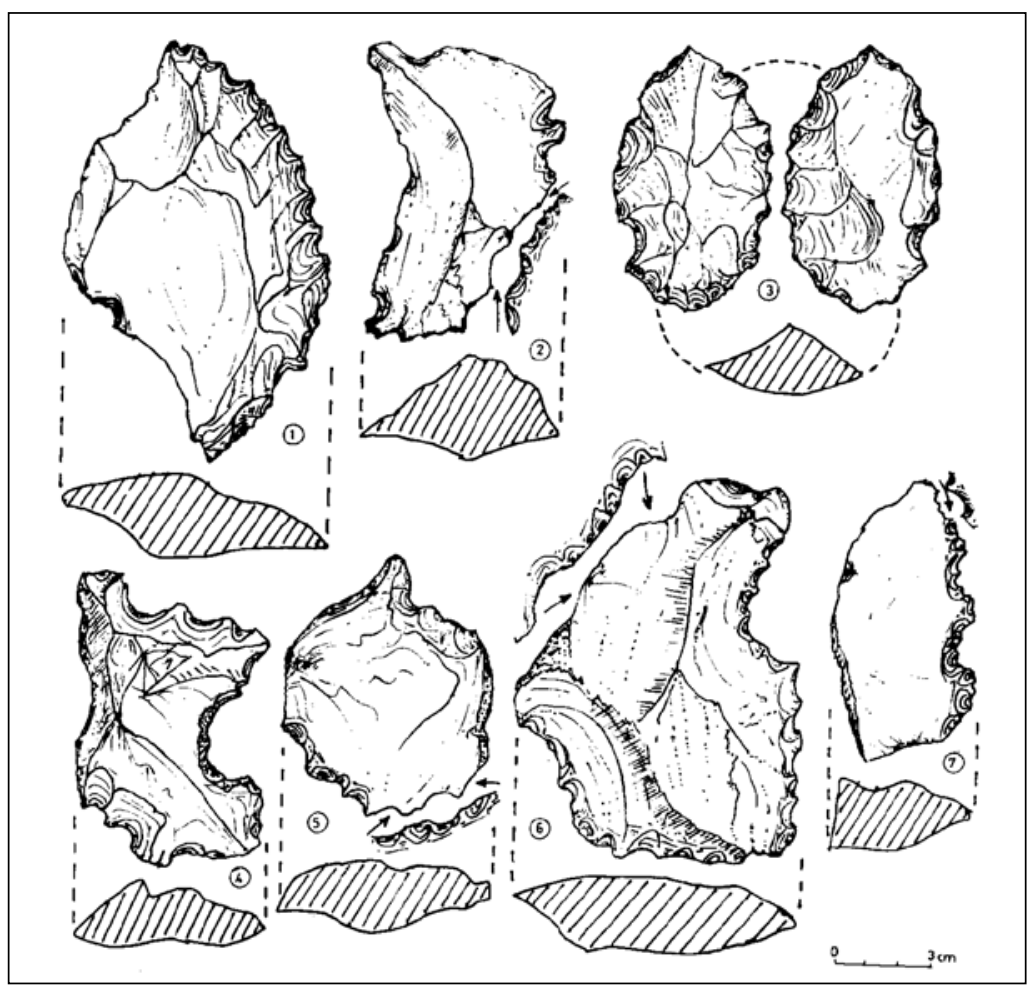

Figura 9. Catalanense: 1) Raedera convexa; 2) Raedera punta roma entre muescas y raspador subrecto convergentes; 3) Bifaz elipsoide (sería raedera de filos convexos convergentes); 4) Raedera cóncava y raspador subrecto y "en hocico" opuesto; 5) Raspador "en hocico" y raedera convexa denticulada; 6) Raedera (doble): cóncava-recta convergentes e ídem leve cóncava opuesta; 7) Raedera denticulada leve convexa. 


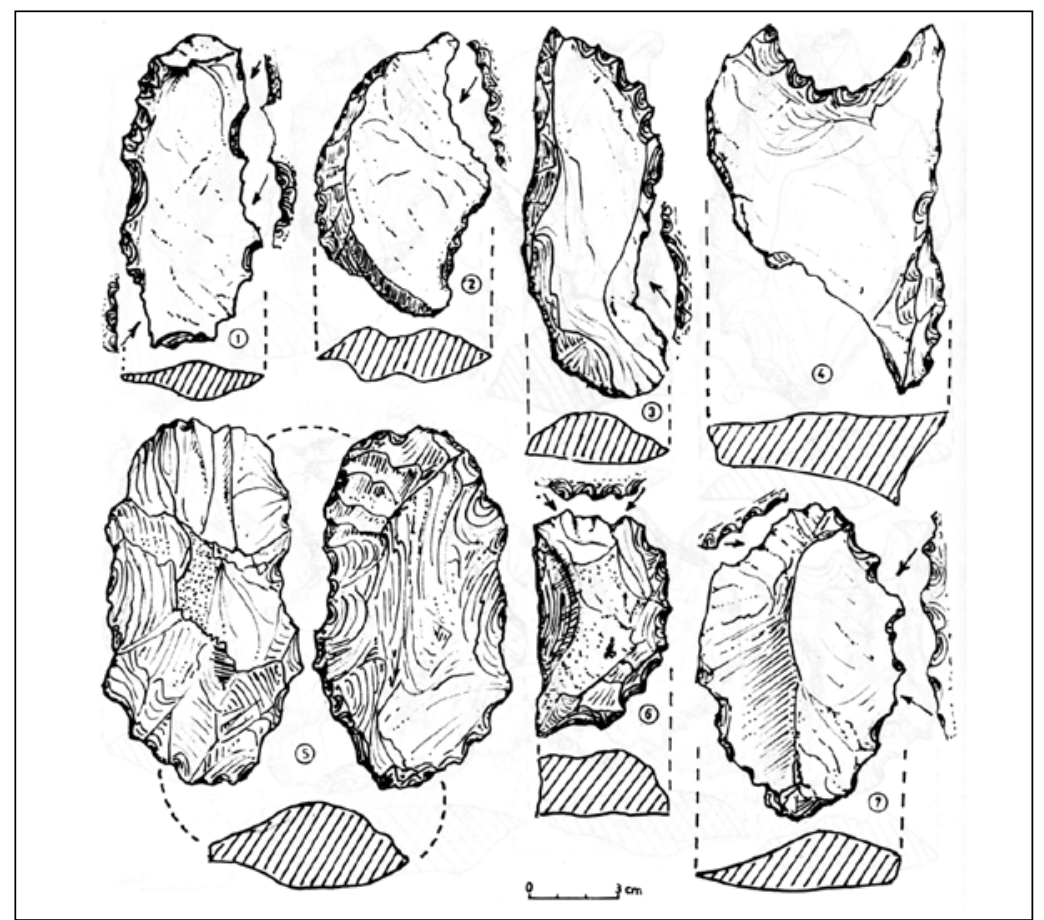

Figura 10. Catalanense: 1) Lámina alargada. Es raedera (doble): convexa y subrecta en laterales; 2) Raedera doble cóncava convergentes en lateral; 3) Raedera (doble): cóncavo-convexa convergentes en lateral; 4) Raedera simple cóncava; 5) Bifaz elipsoide incompleto (sería raedera de filos convexos convergentes); 6) Raspador semicircular; 7) Raedera doble convexa denticulada con retoques alternantes.

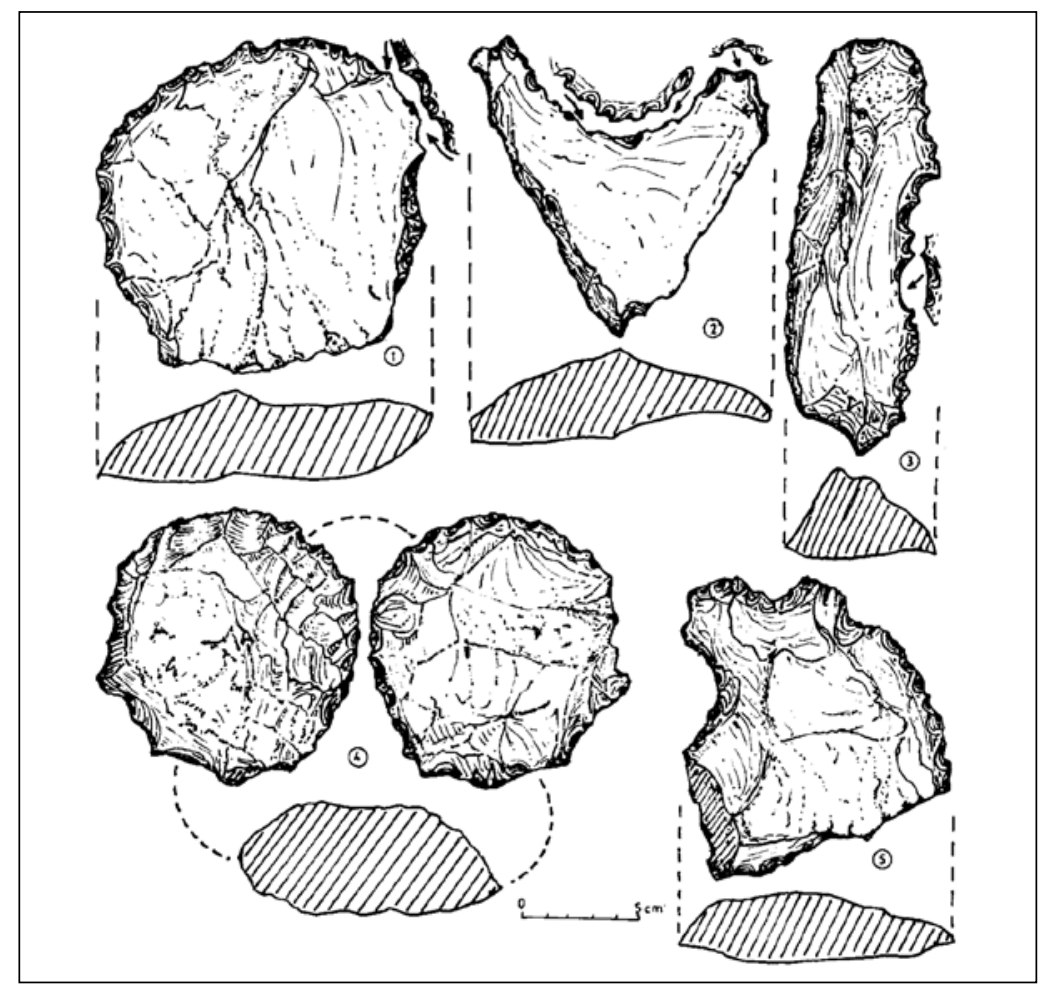

Figura 11. Catalanense: 1) Tajador con talón y filos convexos; 2) Raedera cóncava de filos alternantes; 3) Raedera lateral cóncava con "hocico" central; 4) Tajador con talón y filo bifacial; 5) Gran raedera (doble): cóncava-convexa. 


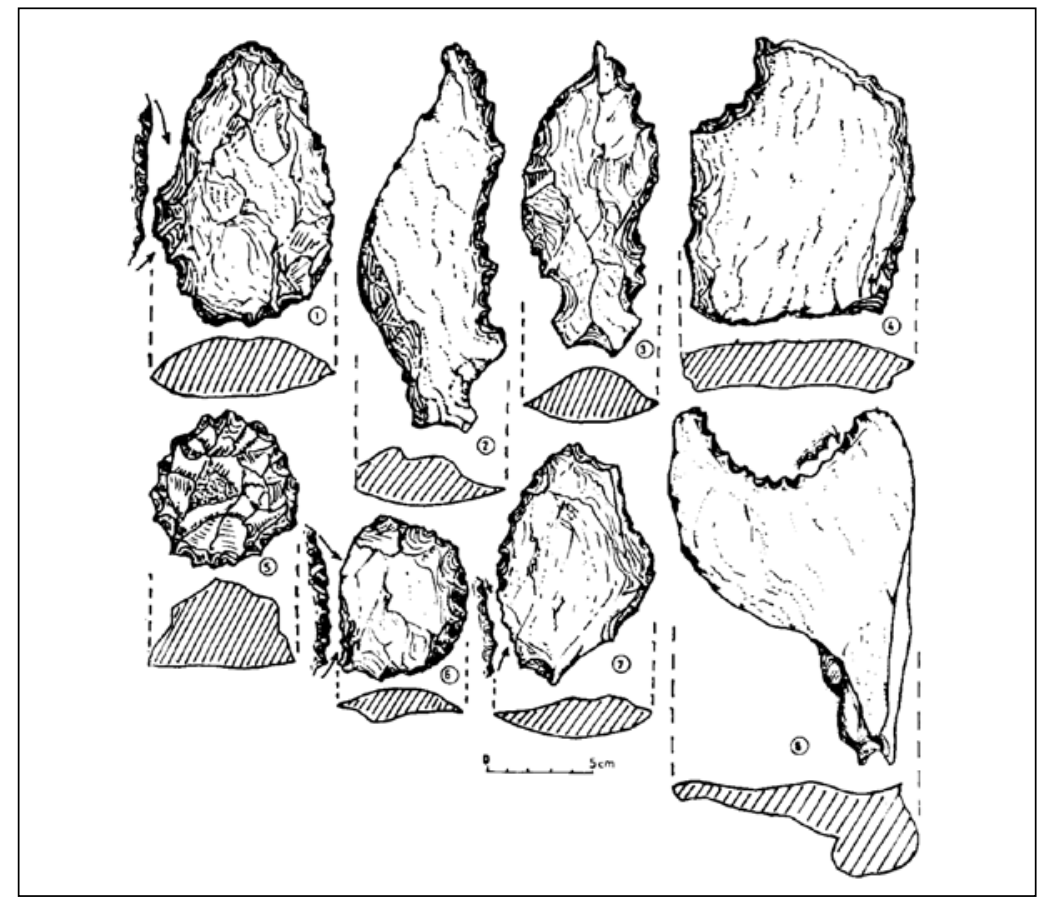

Figura 12. Catalanense: 1) Unifacial sería raedera de filos convexos convergentes; 2) Raedera denticulada (doble): recta-cóncava convergentes en lateral; 3) Unifacial (perforador apical y raedera convexa y convexo-cóncava en laterales); 4) Muesca amplia retocada;

5) Raspador nucleiforme piramidal con perímetro totalmente retocado; 6) Raedera (doble): convexa-recta alternas; 7) Raedera (doble): cóncava-convexa opuestas; 8) Raedera cóncava con retoques alternantes.

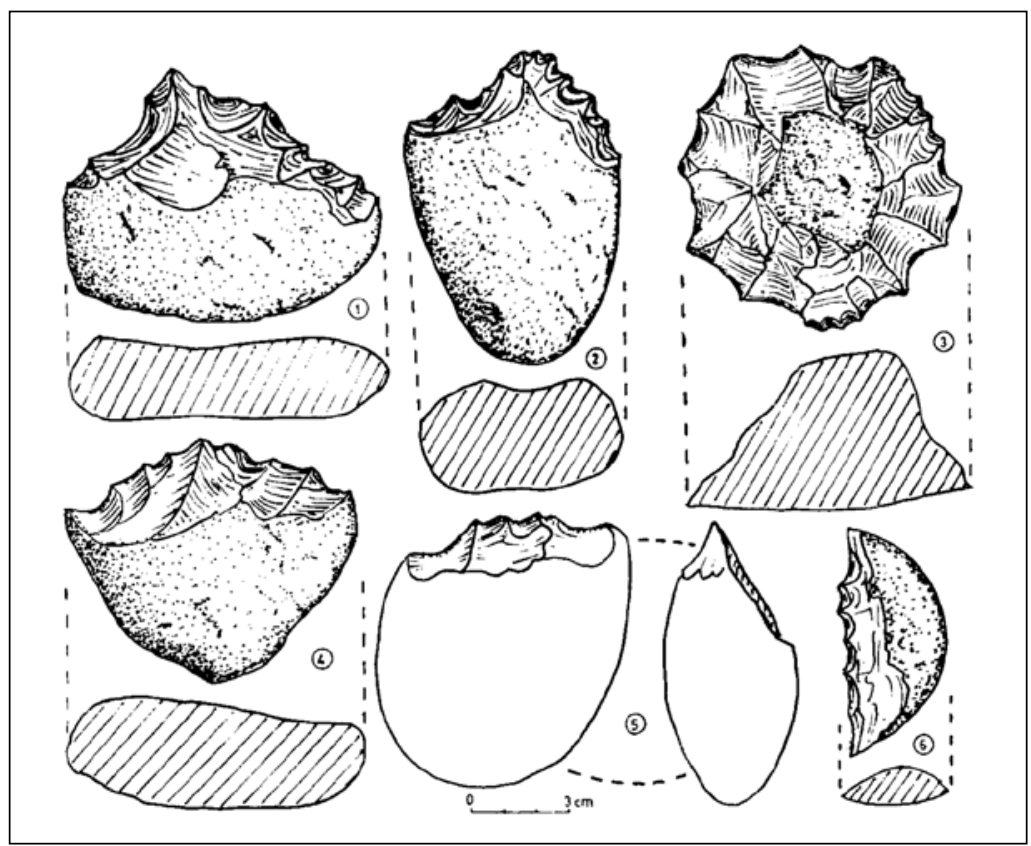

Figura 13. Industria del "cuareimense” o ¿paleoagricultores?: 1) Raspador lateral en punta (guijarro); 2) Raspador apical en punta roma (guijarro); 3) Raspador nucleiforme piramidal (guijarro); 4) Raspador lateral convexo (guijarro); 5) Raspador leve convexo (guijarro); 6) Raspador simple recto en segmento de guijarro. 


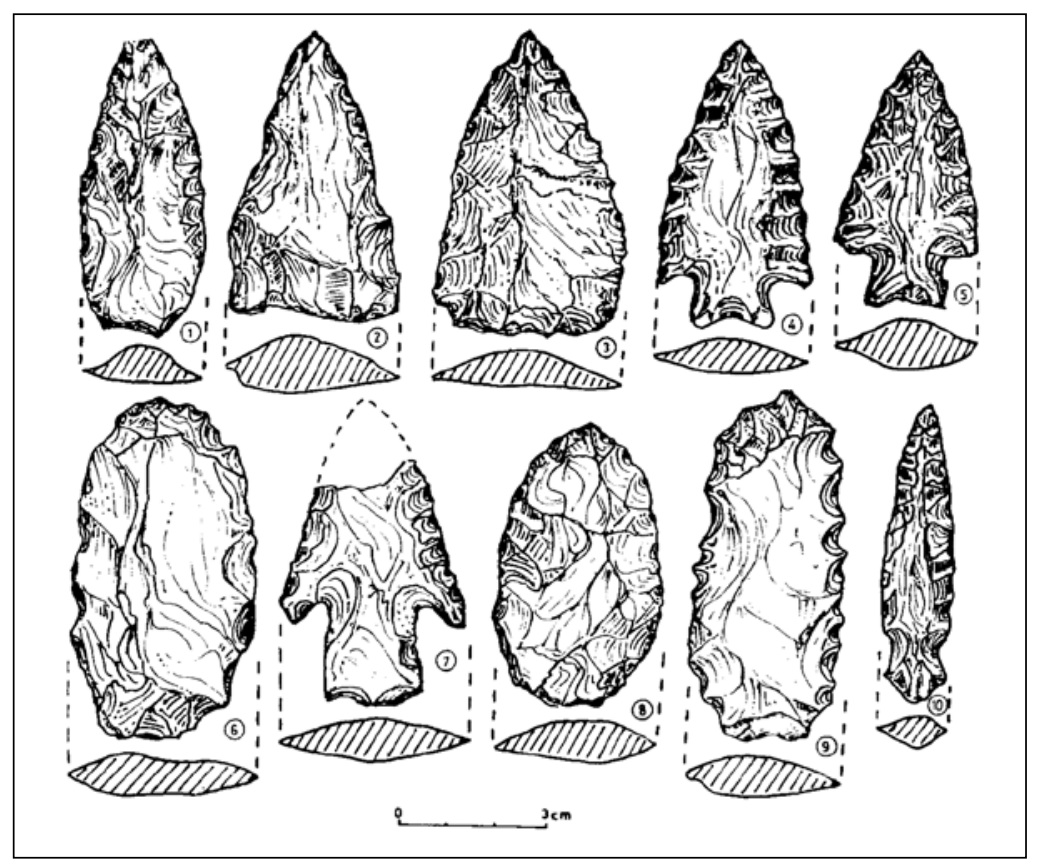

Figura 14. Cazadores superiores o Paleoindio: 1) Punta de proyectil bifacial apedunculada lanceolada; 2 y 3 ) Puntas de proyectil bifaciales apedunculadas triangulares de base subrecta; 4, 5 y 7) Puntas de proyectil bifaciales pedunculada con aletas; 6, 8 y 9) Bifaces elipsoide, foliáceo y lanceolado. Serían raederas de filos convexos convergentes y preformas de puntas de proyectil; 10) Punta de proyectil bifacial con aletas insinuadas.

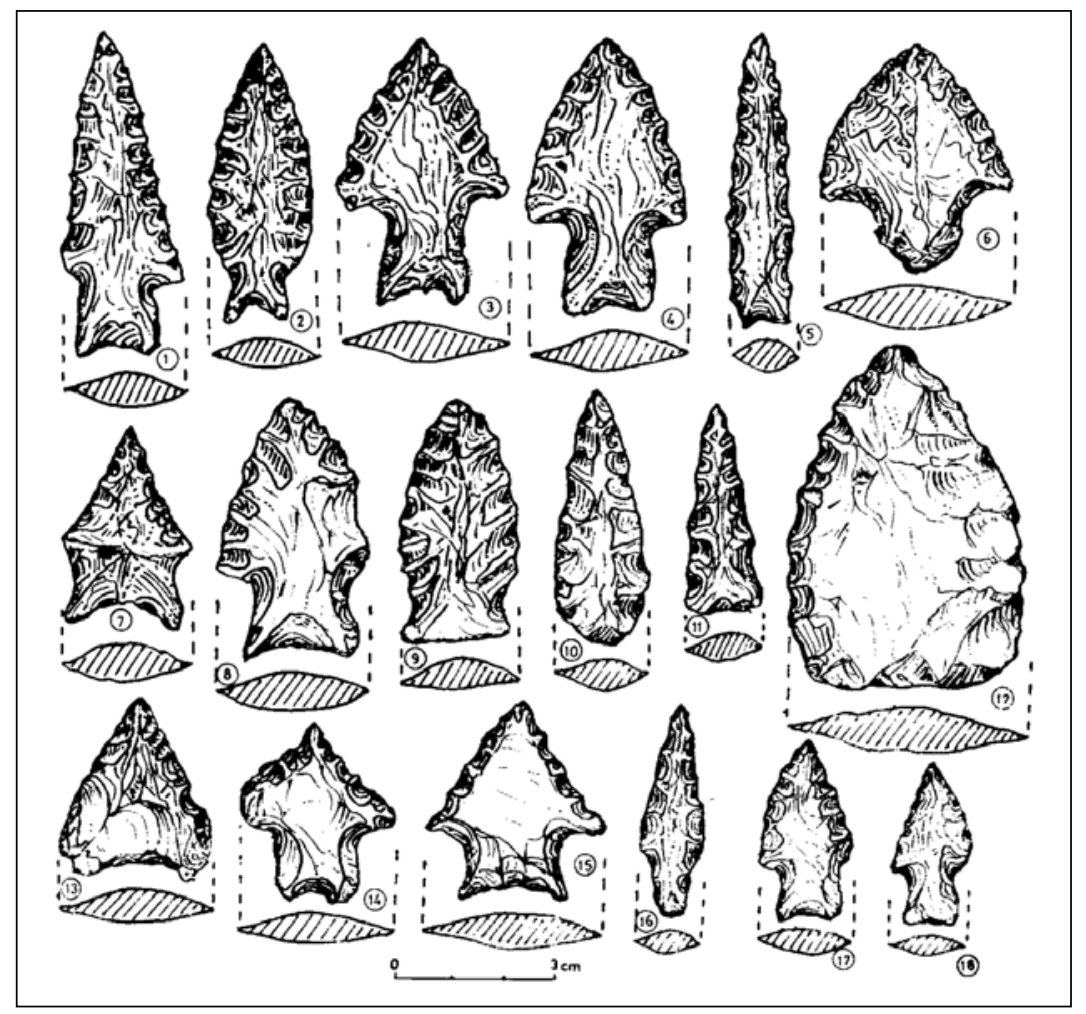

Figura 15. Cazadores superiores o Paleoindio: 1, 2, 3, 4, 6, 7, 8, 15, 17 y 18) Puntas de proyectil bifaciales pedunculadas con aletas de variadas morfologías; 5, 9, 11 y 16) Puntas de proyectil bifaciales pedunculadas con aletas insinuadas; 14) Punta de proyectil bifacial pedunculada retomada; 10) Punta de proyectil bifacial apedunculada lanceolada; 12 y 13) Puntas de proyectil bifaciales apedunculadas triangulares. 


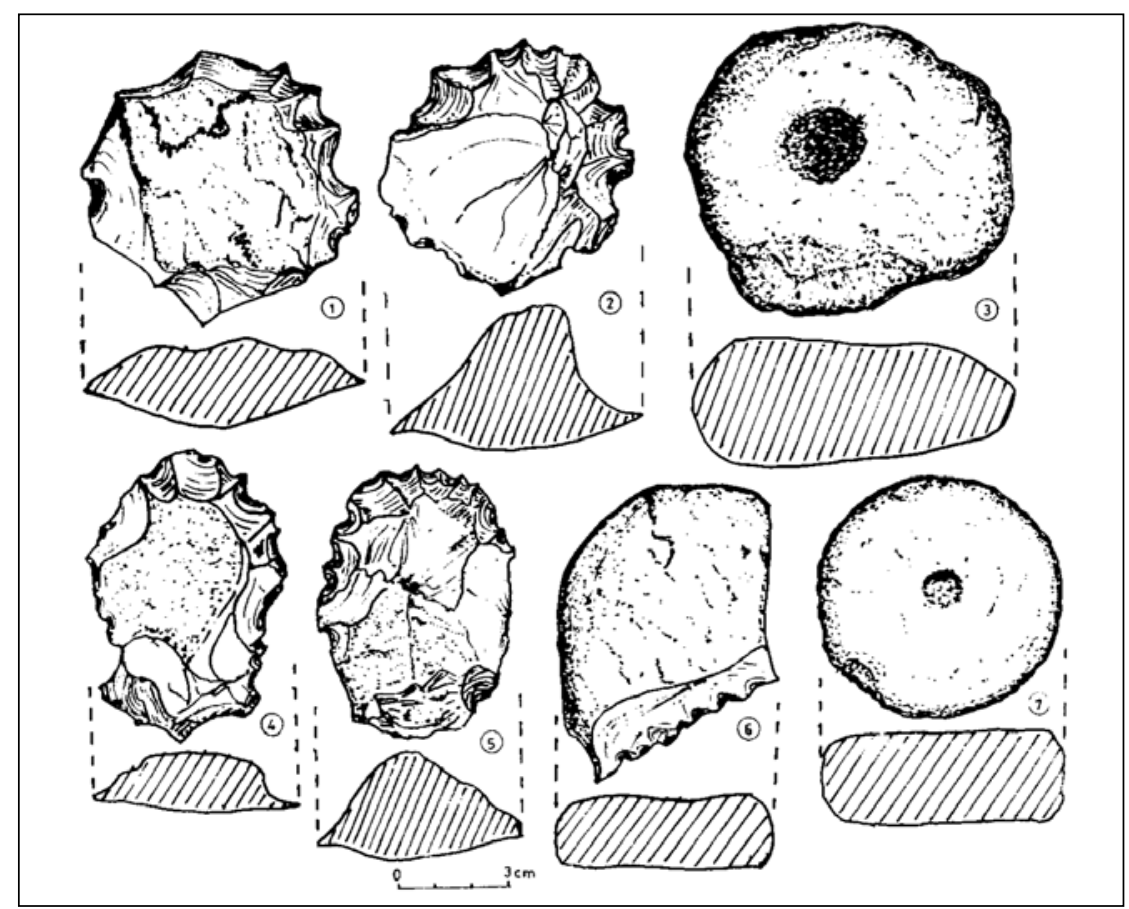

Figura 16. Cazadores superiores o Paleoindio: 1) Raedera subcircular; 2) Raspador piramidal, base subcircular con perímetro totalmente retocado (lasca); 3) Piedra arenisca (abrasiva) con hoyuelo tosco; 4) Raspador (doble) lateral y apical de filos en biseles convexos;

5) Raspador apical de filo en bisel convexo; 6) Raspador filo en bisel subrecto (clasto); 7) Mano circular de molino plano.

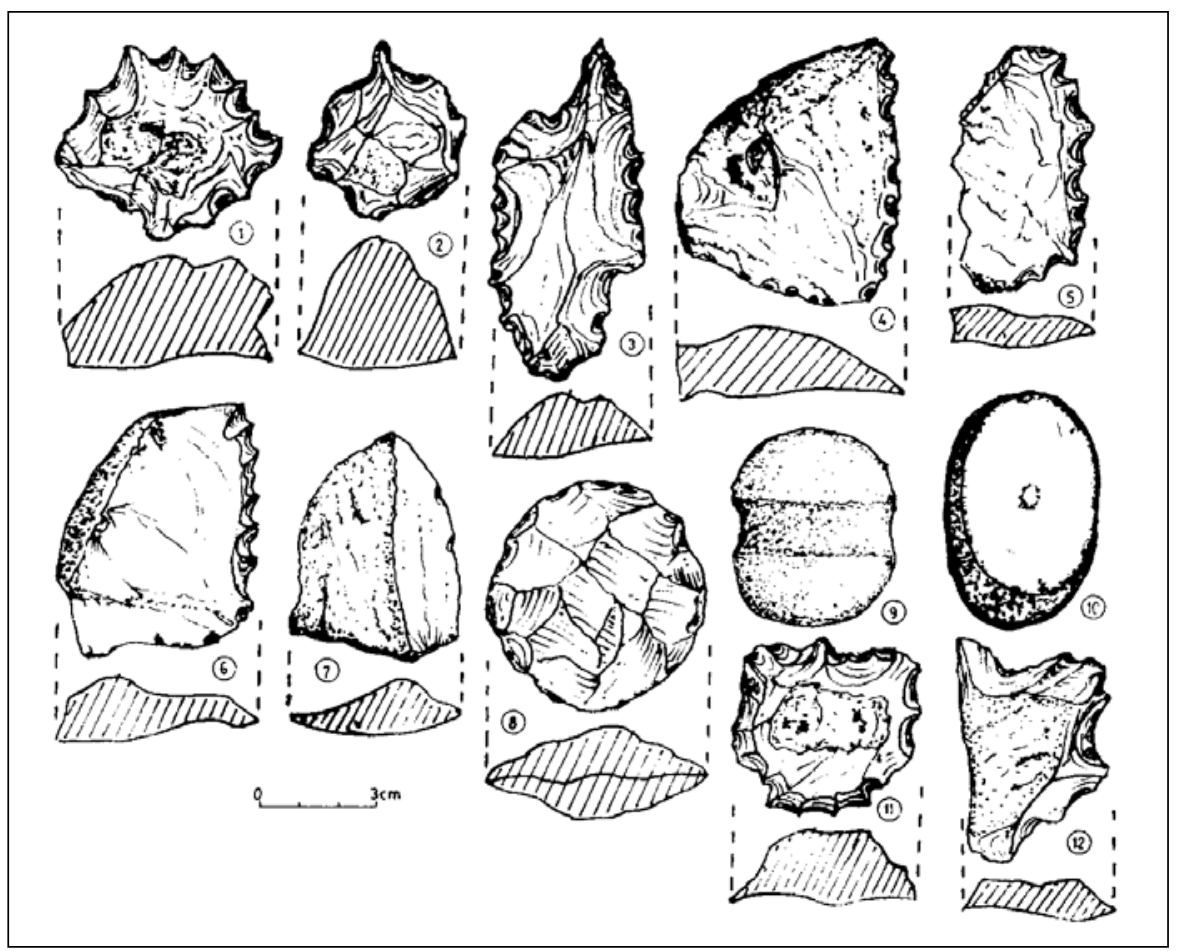

Figura 17. Cazadores superiores o Paleoindio: 1) Raspador nucleiforme con denticulados; 2) Raspador nucleiforme con punta; 3) ¿Perforador? que anexa raspadores laterales convexos; 4) Raedera leve convexa; 5) Raspador leve convexo en lateral; 6) Raedera convexa denticulada; 7) Lasca con filo natural ¿cuchillo?; 8) Piedra de honda (lenticular); 9) Piedra de boleadora; 10) Mano de molino plano (con hoyuelo); 11) Raspador de filos múltipes; 12) Doble muesca que produce raspador "en hocico". 


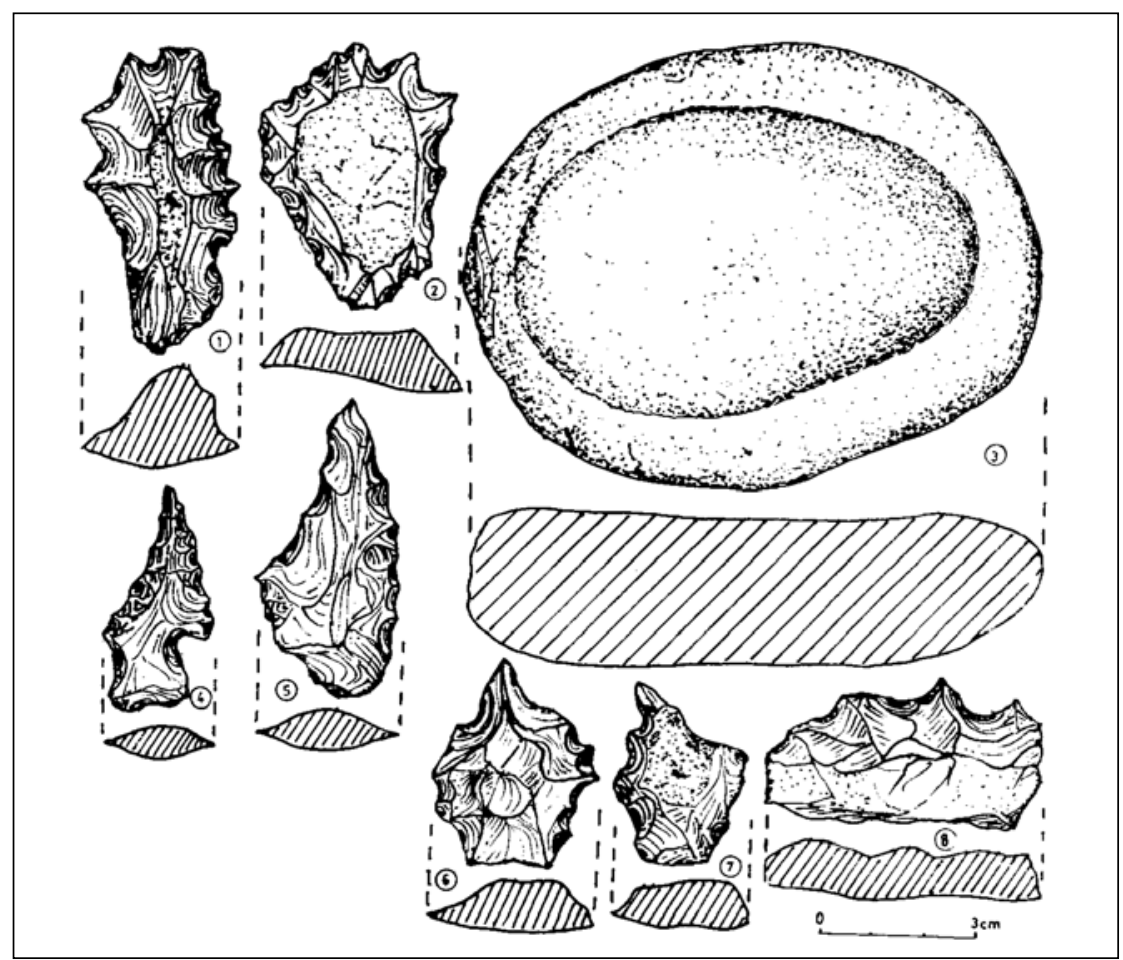

Figura 18. Cazadores superiores o Paleoindio: 1) Raspador denticulado apical y lateral; 2) Raspador apical y lateral denticulado; 3) Molino plano de tipo mediano; 4 y 5) Artefacto compuesto con perforador y raedera cóncava ("hoces"); 6 y 7) Perforadores típicos; 8) Raspador convexo en lateral.

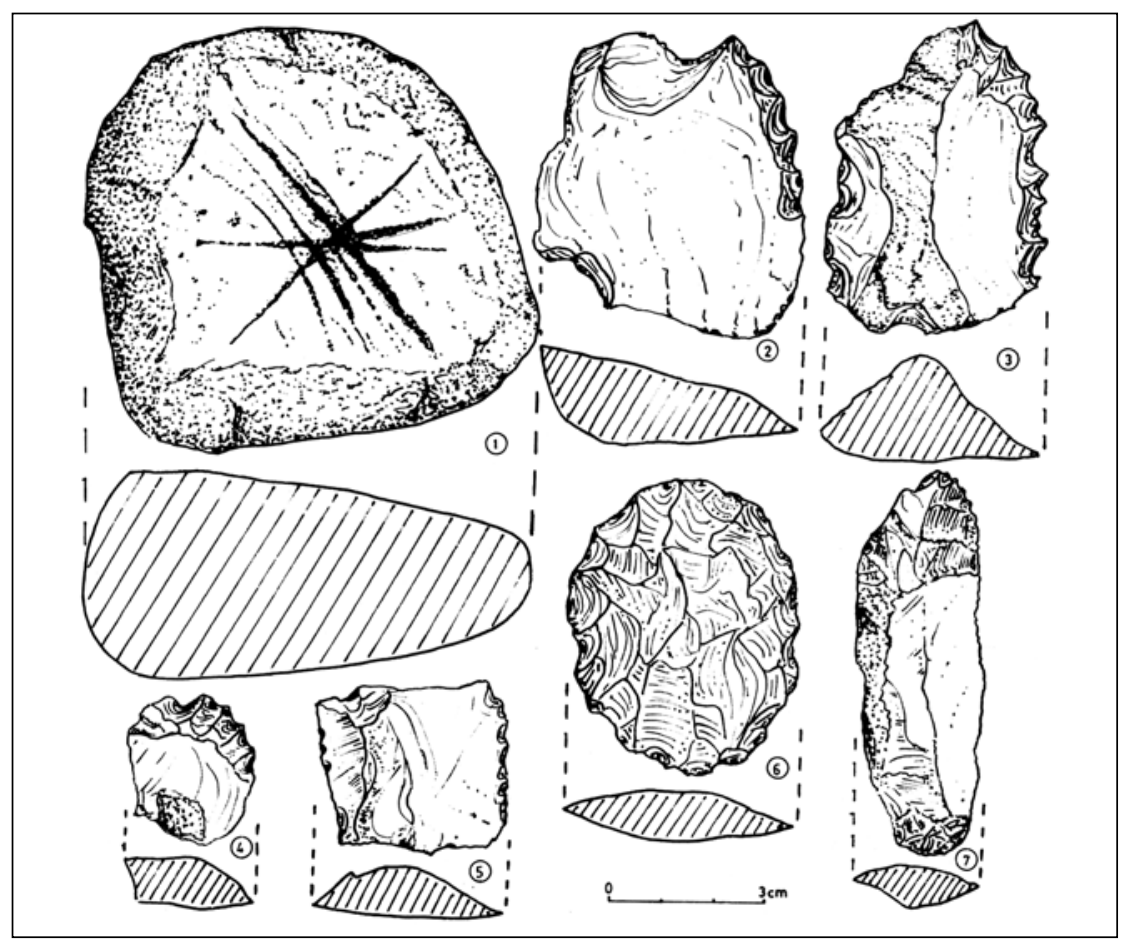

Figura 19. Cazadores superiores o Paleoindio: 1) ¿Afilador de hueso y/o madera?; 2) Raedera simple convexa; 3) Raedera simple recta denticulada; 4) Pequeño raspador de filo en bisel convexo; 5) Raedera simple recta; 6) Bifaz elipsoide (sería raedera de filos convexos convergentes o preforma de punta de proyectil); 7) Hoja filosa con retoques finos ¿cuchillo? y raspador apical convexo. 


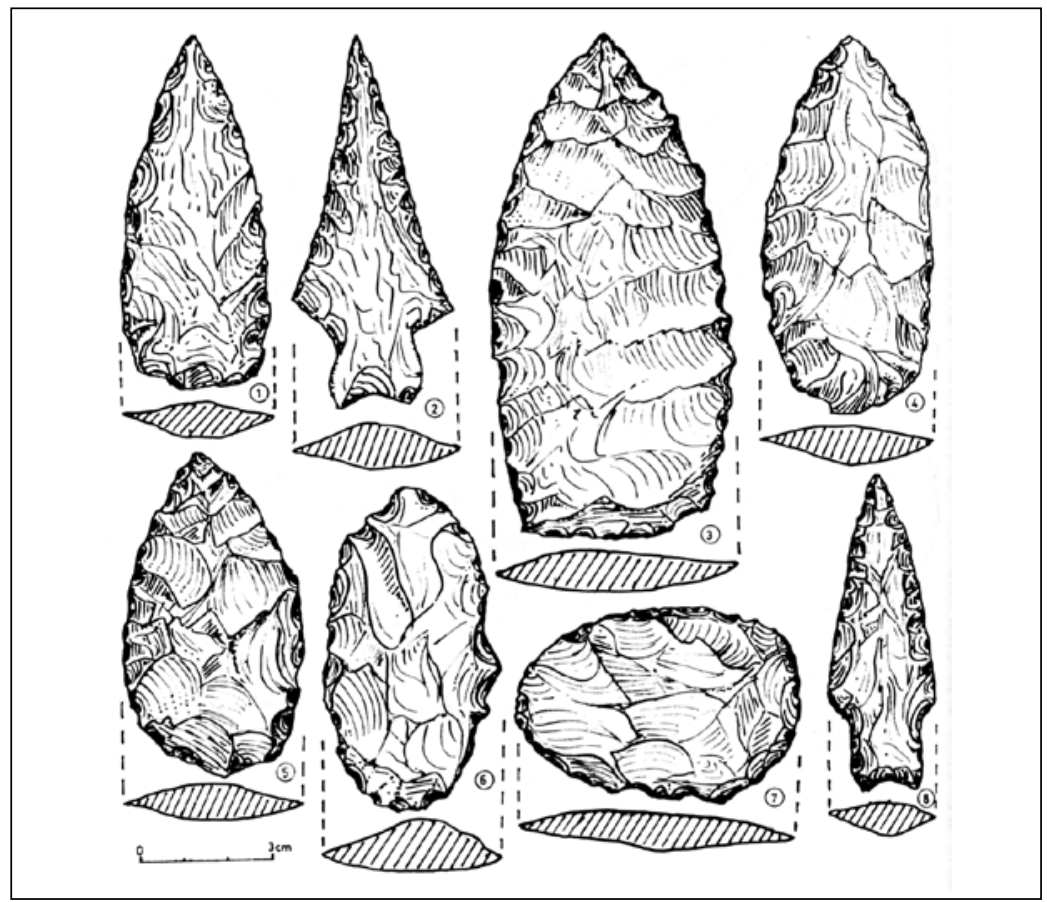

Figura 20. Cazadores superiores o Paleoindio: 1, 4 y 5) Puntas de proyectil bifaciales apedunculadas de bases convexas; 2 y 8) Puntas de proyectil bifaciales pedunculadas con aletas; 3) Punta de proyectil bifacial apedunculada de base subrecta; 6 y 7) Bifaces elipsoides (serían raederas de filos convexos convergentes y preformas de puntas de proyectil).

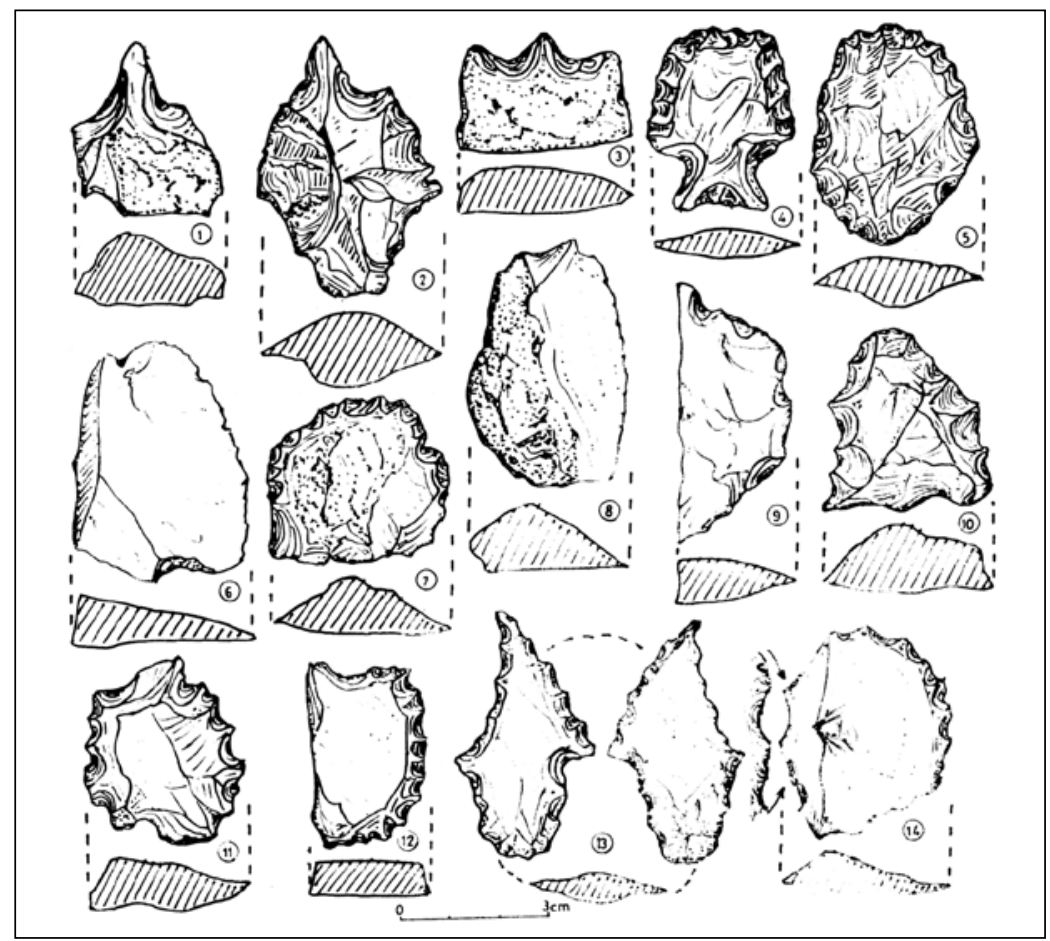

Figura 21. Cazadores superiores o Paleoindio: 1 y 2) Perforadores típicos; 3) Raspador-punta entre muescas; 4) Punta de proyectil retomada en raspador apical; 5) Bifaz elipsoide (sería raedera de filos convexos y preforma de punta de proyectil); 6 y $\mathbf{8}$ ) Lascas filosas con dorso lateral (serían cuchillos); 7) Raspador de filos múltiples; 9) Perforador retomado en bifaz fragmentado; 10) Raspador doble convexo convergentes; 11) Raspador recto y en punta y raedera convexa denticulada; 12) Raspador cóncavo-convexo convergentes; 13) Artefacto compuesto con perforador y raedera cóncava ("hoces”); 14) Raedera simple convexa en reverso y talón retocado alterno. 
